See discussions, stats, and author profiles for this publication at: https://www.researchgate.net/publication/300316780

\title{
Sponge Grounds as Key Marine Habitats: A Synthetic Review of Types, Structure, Functional Roles, and Conservation Concerns
}

\section{Chapter · April 2016}

DOI: 10.1007/978-3-319-17001-5_24-1

\section{CITATIONS}

10

17 authors, including:

Manuel Maldonado

Spanish National Research Council

125 PUBLICATIONS 3,487 CITATIONS

$$
\text { SEE PROFILE }
$$

Raymond John Bannister

Institute of Marine Research in Norway

32 PUBLICATIONS 418 CITATIONS

SEE PROFILE
1,765

Q Ricardo Aguilar

Oceana

57 PUBLICATIONS 354 CITATIONS

SEE PROFILE

James Bell

Victoria University of Wellington

202 PUBLICATIONS 3,091 CITATIONS

SEE PROFILE

Some of the authors of this publication are also working on these related projects:

Project Atlantic sponges View project

Project Transgenerational acclimation of sponges in a changing environment View project 


\title{
Sponge Grounds as Key Marine Habitats: A Synthetic Review of Types, Structure, Functional Roles, and Conservation Concerns
}

\author{
Manuel Maldonado, Ricardo Aguilar, Raymond J. Bannister, James J. \\ Bell, Kim W. Conway, Paul K. Dayton, Cristina Díaz, Julian Gutt, \\ Michelle Kelly, Ellen L. R. Kenchington, Sally P. Leys, Shirley A. \\ Pomponi, Hans Tore Rapp, Klaus Rützler, Ole S. Tendal, Jean \\ Vacelet, and Craig M. Young
}

\section{Contents}

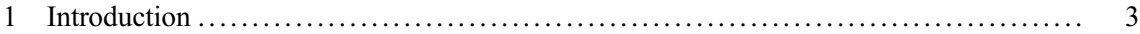

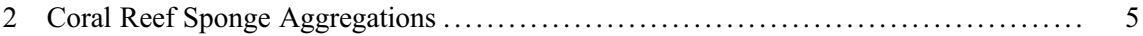

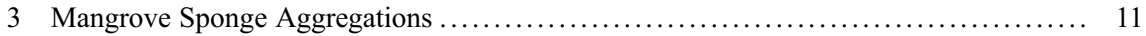

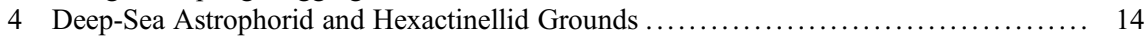

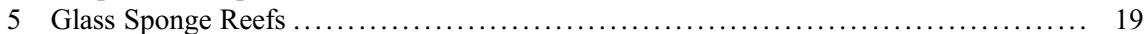

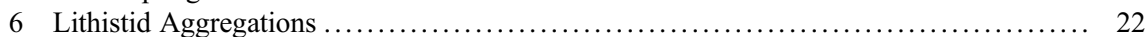

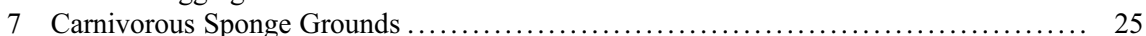

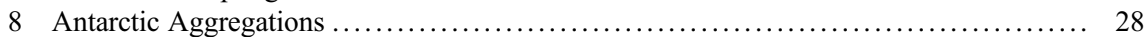

M. Maldonado $(\bowtie)$

Center for Advanced Studies of Blanes (CEAB-CSIC), Girona, Spain

e-mail: maldonado@ceab.csic.es

R. Aguilar

Oceana, Madrid, Spain

e-mail: raguilar@oceana.org

R.J. Bannister

Institute of Marine Research, Bergen, Norway

e-mail: raymond.bannister@imr.no

J.J. Bell

Victoria University of Wellington, Wellington, New Zealand

e-mail: james.bell@vuw.ac.nz

K.W. Conway

Geological Survey of Canada, Pacific Geoscience Centre, Sidney, BC, Canada

e-mail: Kim.Conway@NRCan-RNCan.gc.ca

P.K. Dayton

University of California, San Diego, La Jolla, CA, USA

e-mail: pdayton@ucsd.edu 


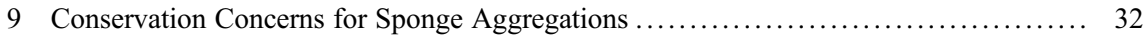

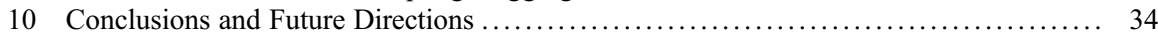

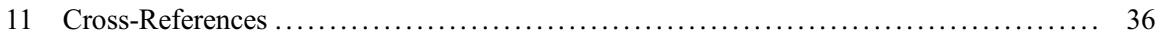

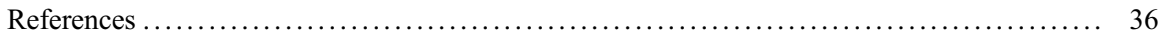

\section{Abstract}

This chapter reviews the major known monospecific and multispecific sponge aggregations in the world's oceans. They are shown to occur from the intertidal to abyssal depths, in tropical, temperate, and high latitudes and sometimes to create

C. Díaz

Museo Marino de Margarita, Boca de Rio, Nueva Esparta, Venezuela

e-mail: taxochica@gmail.com

J. Gutt

Helmholtz Centre for Polar and Marine Research, Alfred Wegener Institute, Bremerhaven, Germany

e-mail: julian.gutt@awi.de

M. Kelly

National Institute of Water and Atmospheric Research (NIWA), Auckland Central, Auckland, New Zealand

e-mail: michelle.kelly@niwa.co.nz

E.L.R. Kenchington

Bedford Institute of Oceanography, Dartmouth, NS, Canada

e-mail: Ellen.Kenchington@dfo-mpo.gc.ca

S.P. Leys

University of Alberta, Edmonton, AB, Canada

e-mail: sleys@ualberta.ca

\section{S.A. Pomponi}

Harbor Branch Oceanographic Institute, Florida Atlantic University, Fort Pierce, FL, USA

e-mail: SPomponi@fau.edu

H.T. Rapp

University of Bergen, Bergen, Norway

e-mail: Hans.Rapp@bio.uib.no

K. Rützler

National Museum of Natural History (NMNH), Smithsonian Institution, Washington, DC, USA e-mail: ruetzler@si.edu

O.S. Tendal

Natural History Museum of Denmark, København, Denmark

e-mail: OSTendal@snm.ku.dk

J. Vacelet

Institut Méditerranéen de Biodiversité et d'Ecologie marine et continentale, Marseille, France

e-mail: Jean.vacelet@imbe.fr

C.M. Young

Oregon Institute of Marine Biology (OIMB-UO), Charleston, OR, USA

e-mail: cmyoung@darkwing.uoregon.edu 
spectacular formations, such as glass sponge reefs, lithistid reef-like fields, and carnivorous sponge grounds. Sponge aggregations are recognized as singular vulnerable habitats that deserve special research attention and legal protection. However, this review reveals that there is only a poor and fragmentary understanding of the main biological, environmental, and geochemical factors that favor and maintain these systems, including the food supply, which is fundamental knowledge. There is also a particular lack of information regarding reproductive biology, growth rates, life spans, and the main factors causing mortality, all crucial drivers for understanding population and community dynamics and for developing conservation strategies. The sponge aggregations have been shown to increase the structural complexity of the habitats, attracting a larger variety of organisms and locally enhancing biodiversity. From the very few cases in which sponge biomass and sponge physiology have been reliably approached jointly, phenomenal fluxes of matter and energy have been inferred. Through their benthic-pelagic coupling, some of the densest sponge aggregations have a significant local or regional impact on major biogeochemical cycles and food webs. Physical damage and habitat destruction derived from man-driven activities along with epidemic diseases facilitated by global environmental alterations emerge as major threats to the future of the sponge aggregations.

\section{Keywords}

Porifera $\bullet$ Benthic-pelagic coupling $\bullet$ Food chains $\bullet$ Reef $\bullet$ Mangrove $\bullet$ Deep-sea benthos $\bullet$ Arctic benthos $\bullet$ Antarctic benthos $\bullet$ Conservation biology $\bullet$ Vulnerable habitats

\section{Introduction}

Sponges are common members of many marine benthic communities. Under circumstances that are not yet well understood, they may undergo exceptional proliferation, forming spectacular aggregations that can be constituted by either a single species or mixed species assemblages. Sponge aggregations are known to occur at virtually all depths, from the intertidal (Fig. 1a-c) to the abyssal zone, and sometimes in quite extreme environments (Fig. 1d). Their extension can range from a few hundreds of $\mathrm{m}^{2}$ to hundreds of $\mathrm{km}^{2}$. More importantly, whenever sponges aggregate, they do not only substantially increase the tridimensional structure of the benthic habitat and its associated biodiversity, but they also affect the hydrodynamics of the deep boundary layer, the circulation and recycling of crucial marine nutrients and, in general, the matter and energy transfer between the water column and the benthos. This chapter summarizes the most remarkable types of sponge aggregations known in the ocean to date. It compiles and reviews information on their particular geographical and environmental settings, taxonomic composition, basic organization features, and ecological significance. 

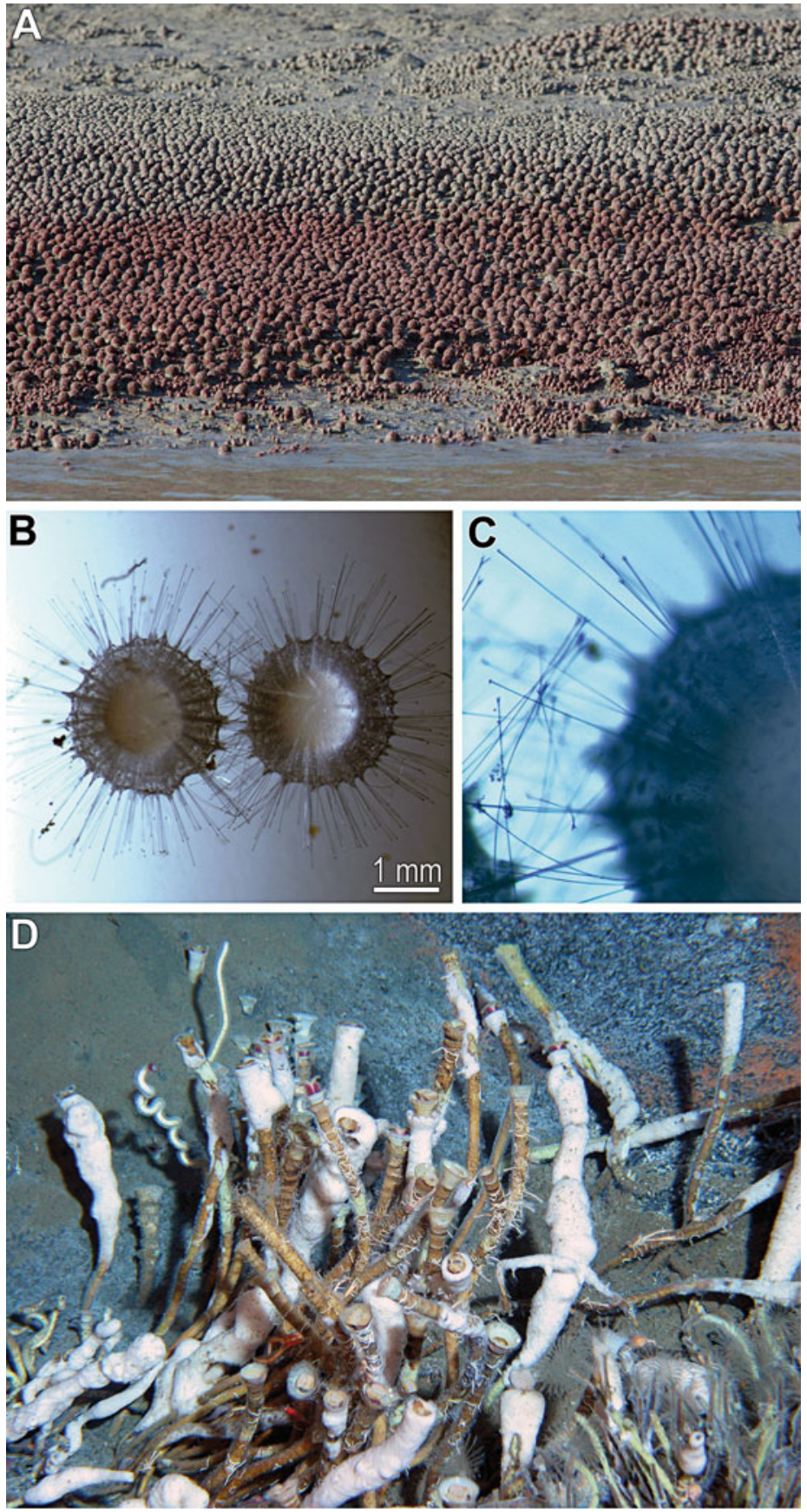

Fig. 1 Examples of sponge aggregations at unusual habitats. (A) View of an extremely dense monospecific aggregation of spirophorid demosponges (preliminarily identified as Craniella sp. by 


\section{Coral Reef Sponge Aggregations}

There are two major coral reef areas in the world ocean. One is the tropical and subtropical Atlantic Ocean (TSAO). The "Greater Caribbean," from Bermuda in the North to Venezuela in the South, probably has the lushest reef development in the TSAO. The other major reef area is the Indo-Pacific, which includes the Great Barrier Reef (GBR) in Australian waters and the "Coral-Triangle" (CT) region, which encompasses areas in the western Pacific Ocean and eastern Indian Ocean.

Sponges of the class Demospongiae are important components, both in diversity and biomass, throughout the world's coral reefs. Typically, coral reefs develop on the continental and island coasts where sea surface temperatures do not fall below a yearly average of $21^{\circ} \mathrm{C}$, practical salinity oscillates between 30 and 40, and sediment input is low. Physicochemical and biological factors (wave action, sediment, light, substrate, oxygen, nutrients, competition, predation, and symbiosis) further shape patterns of sponge distributions across reef systems.

Across Caribbean coral reefs, massive demosponges in the forms of tubes, fans, vases, branches, or balls from genera such as Agelas, Aplysina, Xestospongia, Callyspongia, Niphates, Mycale, and Geodia flourish. Nevertheless, much of the diversity is comprised of sciophilous species, primarily crusts and small cushions dwelling on the underside of coral plates, inside reef crevices and caves, and excavating substrata. These cryptic habitats harbor hundreds of sponges, many still undescribed. Sponge abundance in the Caribbean varies across coral reef profiles. Below $6 \mathrm{~m}$ depth, where sponges are not exposed to wave surge and heavy sedimentation, but still enjoy sufficient nutrient transport, the highest biomass occurs, particularly peaking around $20 \mathrm{~m}$ depth where competing reef corals thin out due to the reduced light and the increased particulate organic matter concentration. Forereefs host an average sponge biomass that is typically twofold to threefold higher per unit area than on patch reefs (Table 1). However, in some lagoon settings,

Fig. 1 (continued) J. Fromont) while exposed to air during low tide at Porosus Creek, a tributary of the Hunter River in the Kimberley Region of Western Australia. (B, C) Juveniles of Craniella sp. (from Norway) upon hatching from the mother sponge, where they had been produced sexually through direct development (i.e., in absence of a larval stage). The spicules (protriaenes and anatriaenes) protruding out of the body of the released juveniles tangle easily $(\mathbf{C})$ with those of the adults, favoring settlement in aggregation. Nevertheless, if resuspended by turbulences, these unattached juveniles can be easily dispersed by horizontal flows as well. Their persistence in the water column is facilitated by the protruding spicules, which act as buoyancy devices favored by water viscosity at low Reynolds numbers. This physical mechanism is also exploited by another holoplanktonic and meroplanktonic organism, the floatability of which is due to the protrusion of long skeletal structures out of the body, such as radiolarians and unciliated hoplitomella larvae of sponges. (D) View of a dense population of Myxilla (Ectyomyxilla) methanophila highly exposed to toxic methane flows at hydrocarbon seeps of the upper Loussiana slope (Gulf of Mexico). The sponge grows as an encrusting epibiont on vestimentiferan tubeworms. It is able to survive in these unusual conditions through symbiosis with methylotrophic bacteria of the genus Methylohalomonas and polycyclic aromatic hydrocarbon-degrading bacteria of the genera Cycloclasticus and Neptunomona (Arellano et al. 2013) 
ลัष

$\|$ 北

巳 巳

츙 ते

这焉

त

哩. 兽

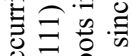

=

혜 $\Xi \Xi$

की के

थै है

을

葫.

के क्षै क्षै

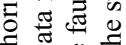

ํํㅇ.

ए

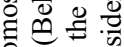

吾咢

记 ఫ

品客专

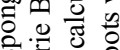

क्ष

过

刍: 导

过

क

ธี. ๖े Ð

\begin{tabular}{|c|c|c|c|c|c|c|c|c|c|c|c|c|c|}
\hline & ถ & $\stackrel{\circ}{\circ}$ & $\because$ & $\stackrel{\circ}{\circ}$ & 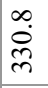 & $\stackrel{0}{\circ}$ & $\stackrel{\circ}{0}$ & $\stackrel{\circ}{\circ}$ & $\stackrel{0}{8}$ & ָ̧ & $\stackrel{\circ}{\circ}$ & $\stackrel{0}{\circ}$ & $\stackrel{\circ}{0}$ \\
\hline$\sum^{\text {जี }}$ & $\stackrel{\infty}{+\infty}$ & $\because$ & $\because$ & $\stackrel{\circ}{\circ}$ & के & $\stackrel{\circ}{\circ}$ & $\because$ & $\stackrel{\circ}{0}$ & 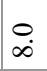 & กุ. & $\because$ & $\stackrel{0}{\circ}$ & $\because$ \\
\hline & ถి & 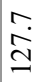 & $\stackrel{\circ}{\circ}$ & $\frac{a}{\sqrt[n]{n}}$ & $\because$ & $\stackrel{\circ}{\circ}$ & $\hat{\circ}$ & $\underset{\infty}{\infty}$ & $\overrightarrow{6}$ & $\stackrel{\circ}{0}$ & $\begin{array}{l}0 \\
\infty \\
\simeq \\
\simeq\end{array}$ & $\stackrel{+}{\infty}$ & $\stackrel{\circ}{\circ}$ \\
\hline
\end{tabular}

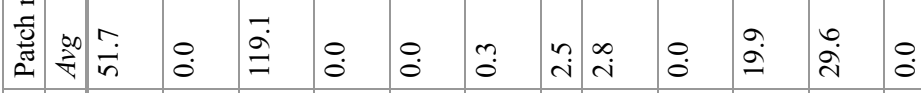

ลิ

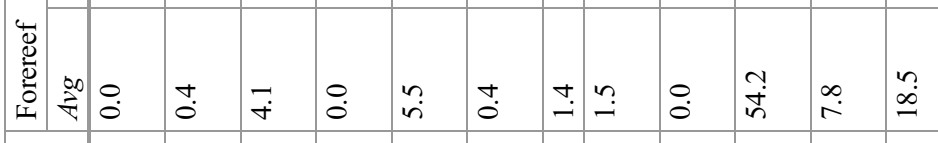

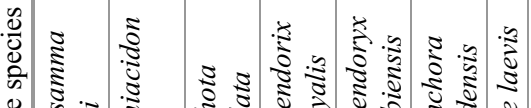

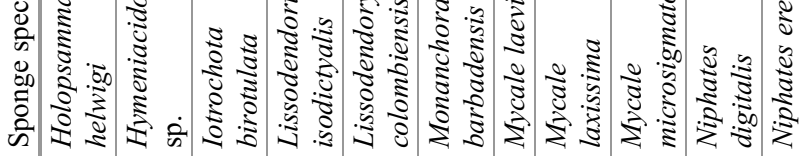

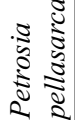

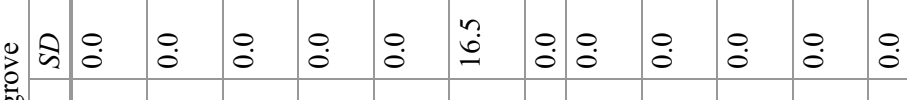

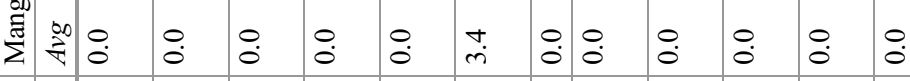

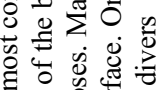

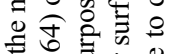

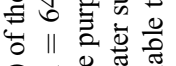

ก $\Xi$.

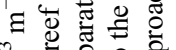

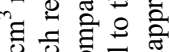

.

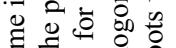

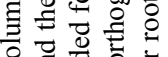

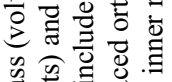

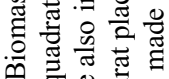

- छ むँّ

๘气

\begin{tabular}{|c|c|c|c|c|c|c|c|c|c|c|c|c|c|}
\hline & ڤి & $\ddot{n}$ & 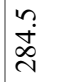 & $\begin{array}{l}\stackrel{0}{0} \\
\stackrel{n}{n}\end{array}$ & ? & $\stackrel{0}{0}$ & $\because$ & 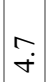 & $\because$ & $\stackrel{\circ}{\circ}$ & $\stackrel{0}{=}$ & $\stackrel{\circ}{0}$ & $\stackrel{\mathfrak{n}}{\mathrm{i}}$ \\
\hline $\begin{array}{c}\bar{D} \\
\text { त्र } \\
0\end{array}$ & $\begin{array}{l}\infty \\
\frac{1}{\nabla}\end{array}$ & $\stackrel{+}{\sim}$ & $\begin{array}{l}\stackrel{n}{i} \\
\underset{y}{2}\end{array}$ & $\begin{array}{l}\infty \\
\infty \\
\infty\end{array}$ & $\overrightarrow{0}$ & $\stackrel{\circ}{0}$ & $\stackrel{\circ}{0}$ & $\begin{array}{l}0 \\
0\end{array}$ & $\stackrel{\circ}{0}$ & $\stackrel{\circ}{0}$ & 9 & $\stackrel{\circ}{0}$ & $\begin{array}{l}\dot{v} \\
\dot{\sigma}\end{array}$ \\
\hline & ڤి & ֶి: & $\begin{array}{l}0 \\
\stackrel{2}{ } \\
\text { o }\end{array}$ & $\overrightarrow{\dot{v}}$ & $\stackrel{n}{\infty}$ & $\stackrel{+}{\stackrel{d}{d}}$ & $\because$ & $\ddot{0}$ & $\stackrel{0}{\dot{r}}$ & $\stackrel{n}{\stackrel{n}{ \pm}}$ & $\stackrel{\circ}{0}$ & $\stackrel{y}{y}$ & 守 \\
\hline 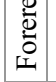 & $\begin{array}{c}\infty \\
\stackrel{\nabla}{\nabla}\end{array}$ & $\begin{array}{l}\infty \\
+\end{array}$ & $\begin{array}{l}\stackrel{+}{\check{2}} \\
\stackrel{2}{2}\end{array}$ & $\hat{i}$ & 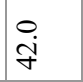 & $\stackrel{\infty}{\forall}$ & $\stackrel{\circ}{0}$ & $\because$ & $\stackrel{+}{0}$ & $\begin{array}{l}\infty \\
i \\
m\end{array}$ & $\stackrel{0}{0}$ & $\begin{array}{l}\stackrel{\sigma}{+} \\
\dot{\sigma}\end{array}$ & $\stackrel{n}{=}$ \\
\hline & $\begin{array}{l}0 \\
0 \\
0 \\
0 \\
0 \\
0 \\
0 \\
0 \\
0 \\
0 \\
0\end{array}$ & 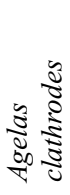 & $\frac{\pi}{0}$ & 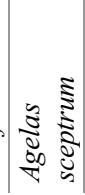 & 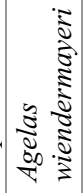 & 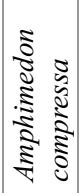 & 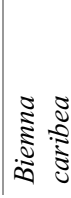 & 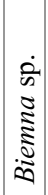 & 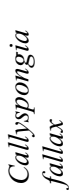 & 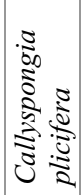 & 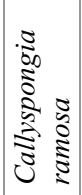 & 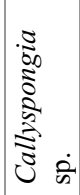 & 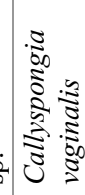 \\
\hline
\end{tabular}




\begin{tabular}{|c|c|c|c|c|c|c|c|c|c|c|c|c|c|c|}
\hline$\stackrel{\circ}{\circ}$ & $\stackrel{\circ}{\circ}$ & $\because$ & $\stackrel{\circ}{0}$ & $\stackrel{0}{0}$ & $a$ & O. & 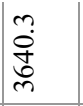 & $\stackrel{\circ}{0}$ & $\ddot{0}$ & $\because$ & $\stackrel{\circ}{0}$ & $\because$ & $\stackrel{\circ}{0}$ & 島 \\
\hline$\stackrel{\circ}{0}$ & $\stackrel{0}{0}$ & $\stackrel{0}{0}$ & $\stackrel{0}{0}$ & $\stackrel{0}{0}$ & $\stackrel{ナ}{\leftrightarrows}$ & $\stackrel{\circ}{0}$ & $\stackrel{2}{\stackrel{2}{g}}$ & $\stackrel{\circ}{0}$ & $\ddot{\circ}$ & $\stackrel{\circ}{0}$ & $\stackrel{\circ}{0}$ & $\ddot{0}$ & $\stackrel{\circ}{0}$ & 蒿 \\
\hline$\stackrel{\circ}{0}$ & $\stackrel{\circ}{0}$ & $\because$ & $\stackrel{\circ}{0}$ & $\because$ & $\vec{a}$ & $\stackrel{\circ}{\circ}$ & $\stackrel{\circ}{0}$ & $\stackrel{\infty}{-}$ & $\stackrel{\circ}{0}$ & $\stackrel{\circ}{0}$ & $\stackrel{\circ}{0}$ & $\begin{array}{l}0 \\
\dot{J} \\
\text { do }\end{array}$ & $\stackrel{\circ}{0}$ & 官 \\
\hline$\stackrel{\circ}{\circ}$ & $\because$ & $\stackrel{0}{0}$ & $\stackrel{0}{0}$ & $\ddot{\circ}$ & $\stackrel{m}{+}$ & $\ddot{0}$ & $\stackrel{\circ}{0}$ & $\stackrel{m}{0}$ & $\stackrel{\circ}{0}$ & $\stackrel{\circ}{0}$ & $\ddot{0}$ & $\begin{array}{l}n \\
\stackrel{2}{0} \\
\infty \\
\infty\end{array}$ & $\stackrel{0}{0}$ & 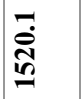 \\
\hline बें & $\stackrel{i}{i}$ & $\begin{array}{l}\infty \\
\infty \\
\infty\end{array}$ & बें & $\cong$ & $\hat{a}$ & $\stackrel{g}{ \pm}$ & $\stackrel{\circ}{0}$ & $\stackrel{\circ}{\circ}$ & $\stackrel{n}{0}$ & $\stackrel{\circ}{\circ}$ & 守 & 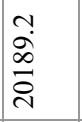 & $\begin{array}{l}0 \\
\stackrel{0}{0} \\
\stackrel{1}{二}\end{array}$ & 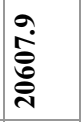 \\
\hline $\begin{array}{l}\infty \\
i \\
i \\
n\end{array}$ & ఫे & $\ddot{0}$ & $\stackrel{\leftrightarrow}{\stackrel{0}{0}}$ & ִָ & $\stackrel{\leftrightarrow}{\dot{r}}$ & $\stackrel{m}{i}$ & $\stackrel{\circ}{0}$ & $\stackrel{\circ}{0}$ & $\ddot{0}$ & $\ddot{o}$ & $\overrightarrow{i n}$ & 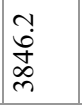 & 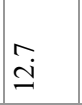 & 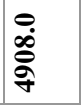 \\
\hline 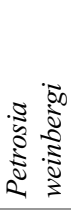 & 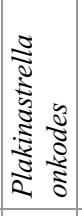 & 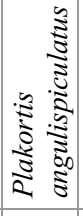 & 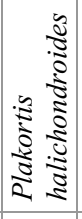 & 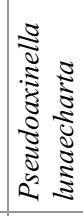 & 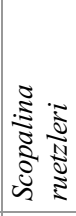 & 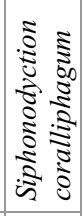 & 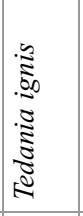 & 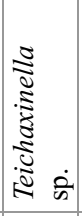 & $\begin{array}{l}\dot{0} \\
\tilde{n} \\
\tilde{\Xi} \\
\tilde{\Xi} \\
\dot{\Xi}\end{array}$ & 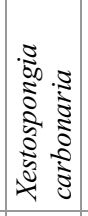 & 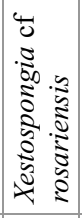 & 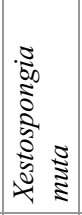 & 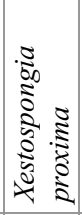 & 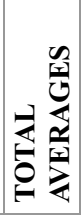 \\
\hline $\begin{array}{l}\infty \\
\stackrel{0}{0} \\
\hat{0}\end{array}$ & $\stackrel{\circ}{\circ}$ & $\because$ & $\stackrel{\circ}{\circ}$ & $\stackrel{\circ}{\circ}$ & $\stackrel{\circ}{\circ}$ & $\stackrel{0}{0}$ & $\stackrel{\circ}{0}$ & $\stackrel{\circ}{\circ}$ & \begin{tabular}{l}
$n$ \\
$\stackrel{n}{2}$ \\
\multirow{2}{*}{}
\end{tabular} & $\stackrel{\circ}{a}$ & $\stackrel{n}{2}$ & $\stackrel{a}{\infty}$ & $\stackrel{\circ}{0}$ & 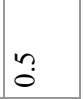 \\
\hline$\hat{\tilde{\lambda}}$ & $\stackrel{\circ}{0}$ & $\stackrel{\circ}{\circ}$ & $\stackrel{\circ}{\circ}$ & $\stackrel{0}{0}$ & $\stackrel{\circ}{0}$ & $\stackrel{\circ}{\circ}$ & $\because$ & $\ddot{0}$ & $\begin{array}{l}0 \\
\infty \\
\infty\end{array}$ & aे & $\begin{array}{l}n \\
n\end{array}$ & $\stackrel{0}{-}$ & $\ddot{0}$ & $\overrightarrow{0}$ \\
\hline$\stackrel{0}{\circ}$ & $\stackrel{\circ}{0}$ & $\stackrel{m}{8}$ & $\begin{array}{l}n \\
ٌ \\
\swarrow\end{array}$ & $\stackrel{\circ}{0}$ & $\stackrel{\circ}{+}$ & $\frac{n}{6}$ & $\stackrel{0}{0}$ & ঠ্ণ & 0 & Oு. & $\stackrel{0}{0}$ & 0 & $\ddot{0}$ & $\because$ \\
\hline$\stackrel{\circ}{\circ}$ & $\stackrel{\circ}{\circ}$ & $\stackrel{m}{\infty}$ & $\stackrel{0}{\circ}$ & $\stackrel{\circ}{\circ}$ & $\stackrel{\infty}{\circ}$ & $\stackrel{\Upsilon}{=}$ & $\stackrel{0}{0}$ & $\begin{array}{l}0 \\
\ddot{\circ} \\
i\end{array}$ & $\stackrel{0}{\circ}$ & $\stackrel{\circ}{\circ}$ & $\stackrel{0}{0}$ & $\ddot{0}$ & $\stackrel{0}{0}$ & $\stackrel{\circ}{0}$ \\
\hline$\stackrel{0}{0}$ & $\stackrel{+}{-}$ & 年 & 9 & $\stackrel{+}{\forall}$ & $\begin{array}{l}\stackrel{0}{2} \\
\stackrel{2}{0}\end{array}$ & $\stackrel{i}{\underline{\sigma}}$ & $\begin{array}{l}n \\
\stackrel{n}{0} \\
2\end{array}$ & 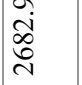 & $\because$ & $\ddot{0}$ & $\ddot{0}$ & $\because$ & $\exists$ & $\stackrel{\circ}{0}$ \\
\hline$\stackrel{\circ}{\circ}$ & $\stackrel{\sim}{0}$ & חֶ. & $\stackrel{m}{0}$ & $\stackrel{\circ}{\circ}$ & ले & $\stackrel{n}{0}$ & ָे & 字 & $\ddot{0}$ & $\because$ & $\ddot{0}$ & $\ddot{0}$ & ִָ & $\because$ \\
\hline 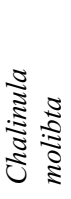 & 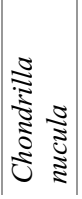 & 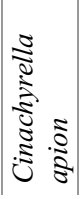 & 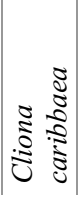 & 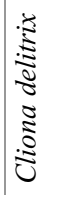 & 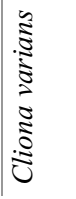 & 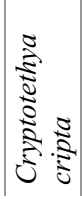 & 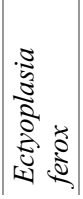 & 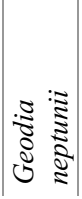 & 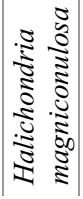 & 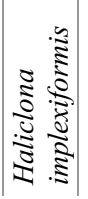 & 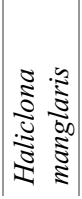 & 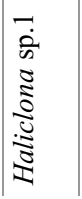 & 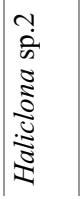 & 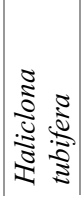 \\
\hline
\end{tabular}


on patch reefs, certain sponges thrive. For example, thick crusts of Chondrilla caribensis form remarkable aggregations at some Caribbean patch reefs, occupying on average $44.7 \% \pm 10.3 \%$ of the hard substratum and even overgrowing corals (Fig. 2a). On forereefs, sponge volume has been estimated at $3 \mathrm{~L} \mathrm{~m}^{-2}$ in Discovery Bay, Jamaica (Reiswig 1973) and at $4.9 \pm 20.6 \mathrm{~L} \mathrm{~m}^{-2}$ on the Belize Barrier Reef (Table 1; Fig. 2b). The latter biomass is made up by 53 common species (Table 1). Scattered, large individuals of Geodia neptuni and Xestospongia muta (Fig. 2c) are responsible for the large variability in sponge volume per $\mathrm{m}^{2}$ of forereef. This latter species, with sizes between 1 and $200 \mathrm{~L}$, occurs at densities ranging from 1 to 27 individuals per $100 \mathrm{~m}^{2}$ on deep reef sites in the Bahamas, the Florida Keys, Colombia, and Belize. At Conch Reef, in the Florida Keys, average mean biomass of $X$. muta alone is estimated at $1.4 \mathrm{~L} \mathrm{~m}^{-2}$, and it appears that biomass is increasing over time.

The Indo-Pacific coral reefs, particularly the "coral triangle" region, support the most diverse sponge assemblages in the world, with a probable very high number of yet undescribed species. While sponges are very abundant on the reef slopes, they also dominate cave and overhanging reef environments. Similar to Caribbean reefs, many large, conspicuous sponges are present, such as the giant barrel sponge Xestospongia testudinaria (Fig. 2d), but again, the diversity levels are often driven by high abundance of very small $\left(<2-3 \mathrm{~cm}^{2}\right)$, encrusting species. Sponge genera absent from the Caribbean reefs, such as the large Ianthella fans and plate-shaped phototrophic sponges (Lamellodysidea, Phyllospongia, and Carteriospongia), are also conspicuous on these reefs. As an example, in the Wakatobi Marine National Park, in Sulawesi, over 130 sponge species have been reported to date with abundance estimates of more than 200 individuals $\mathrm{m}^{-2}$ and occupying more space than corals. In this area, reef degradation has occurred reducing coral cover, while the sponge Lamellodysidea herbacea (Fig. 2e) has increased in abundance (up to 100 individuals $\mathrm{m}^{-2}$ ) and now covers more than $75 \%$ of the substratum in some locations. This species, common throughout the Indo-Pacific, is indeed currently proliferating in a number of locations.

Another striking example is Palmyra Atoll in the central Pacific, where there are contrasting patterns of abundance and diversity in the atoll lagoons compared to outer atoll reefs. The lagoons were heavily modified in the 1940s during World War II and virtually all the coral was removed or destroyed. The hard substratum in the lagoon is now dominated by sponges. Sponge diversity is low, with only 24 species reported, but sponge cover ranges from $20 \%$ to $50 \%$. This contrasts with the nonlagoon reefs, which are considered among the most pristine in the world, and have very few conspicuous sponge species and very low sponge abundance $(<1 \%$ cover).

Sponge populations on the Great Barrier Reef are also rich, having lower overall diversity than the Indian Ocean region but higher diversity than the Pacific Islands. On the Great Barrier Reef, sponge biomass ranges from $0.45 \mathrm{~kg} \mathrm{~m}^{-2}$ on inner reefs to less than $0.2 \mathrm{~kg} \mathrm{~m}^{-2}$ on outer reefs. Importantly, the distribution of sponge biomass in Australian reefs appears to contrast with that in the Caribbean. In a comparative study (Wilkinson and Cheshire 1990), the estimated sponge biomass on 
relatively healthy reefs of the Great Barrier Reef was six times lower than that in Belize, with the highest biomass on inner (lagoon) reefs (1-2.4 $\mathrm{kg}^{-2}$ wet weight $\mathrm{m}^{-2}$ ), followed by barrier back reefs $\left(0.9-1.3 \mathrm{~kg} \mathrm{~m}^{-2}\right)$, and outer reefs $\left(0.3-0.7 \mathrm{~kg} \mathrm{~m}^{-2}\right)$. Whether food availability could be limiting sponges is a hypothesis that needs further exploration and has been proposed in the past to explain the large sponge biomass differences between the Caribbean and Great Barrier Reef forereef assemblages.

In Western Australia, some of the richest sponge assemblages have been reported from Ningaloo Reef Marine Park (Schönberg and Fromont 2012). Estimates suggest that there are more than 500 species on the shelf (at 30-100 m depth) in this region.
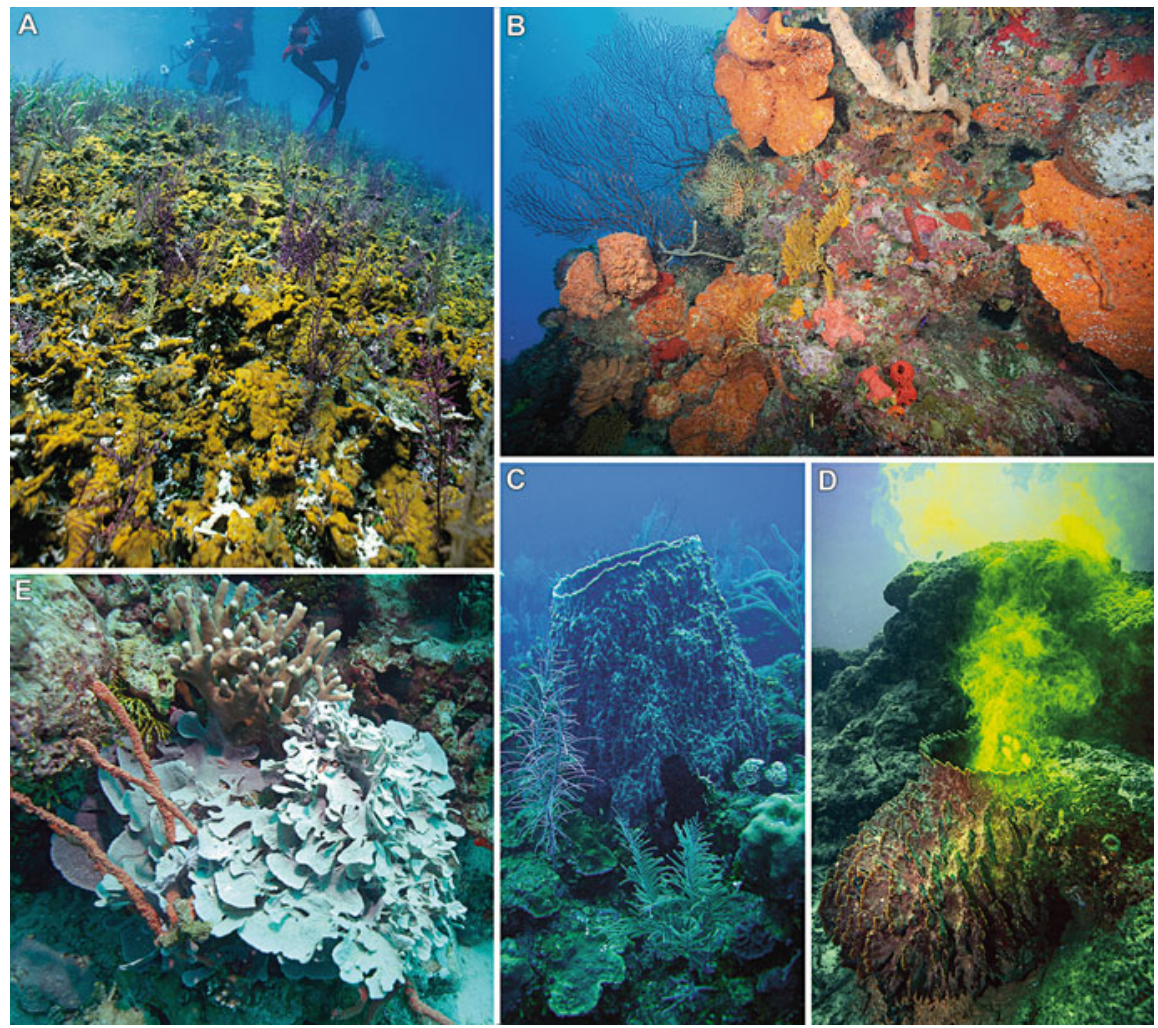

Fig. 2 Views of coral reef sponge aggregations. (A) A dense population of Chondrilla caribensis on a Belizean patch reef covering a large area of substratum, including coral. (B) General view of a shaded overhang on the forereef off Carrie Bow Cay in Belize, dominated by large, orange individuals of Agelas spp and an additional variety of smaller sponges. (C) A mid-size individual of Xetospongia muta on the Belizean forereef. (D) A mid-size individual of Xetospongia testudinaria at Wakatobi Marine National Park (Indonesia), the pumping activity of which is revealed by the injection of fluorescein. (E) View of a large individual of Lamellodysidea herbacea at Wakatobi Marine National Park 
The highest biomass averages at some sites up to $0.5 \mathrm{~kg}$ wet weight $\mathrm{m}^{-2}$, which is about 12 times lower than maxima at the Great Barrier Reef forereefs.

Reef sponges have an impact on the ecosystem as powerful space competitors with feeding-deterrent chemistry and through physiological functions. Coral reef sponges compete for space with sessile invertebrates and algae and live in association with a large spectrum of microbes, algae, invertebrates, and fishes through epibiosis, endobiosis, and symbiosis (Rützler 2012). Furthermore, they are preyed upon by several invertebrates (polychaetes, molluscs, echinoderms, etc.), fishes, and sea turtles. These factors have driven the evolution of natural products chemistry (mostly toxic) among coral reef sponges, which show a comparatively larger diversity of compounds than those characterizing deep-sea sponge assemblages. Through their filter feeding activity, sponges may help to keep reefs in oligotrophic conditions favorable to corals. Indeed, the densest sponge fauna of a Jamaican forereef $(15-50 \mathrm{~m})$ has been estimated to filter daily a volume of water equivalent to the entire water column over the reef bottom, retaining nearly $100 \%$ of the picoplankton and suspended detritus (Reiswig 1974). Sponges also profoundly affect the food chain of coral reefs through additional mechanisms. They take up dissolved organic matter (DOM) that is unavailable to other invertebrates and generate, in exchange, an outflow of particulate organic matter (POM) resulting from metabolic waste and cellular renewal that feeds other invertebrates at basal and intermediate levels of the reef trophic chain (de Goeij et al. 2013; Maldonado 2015). Reef sponges, being consumed by different invertebrates and vertebrates, are also an important resource for higher levels of the food chain in coral reefs. Additionally, sponges influence biogeochemical cycling of dissolved nutrients on coral reefs, particularly of nitrogen and silicon. Many sponges contain a high density of prokaryotes in their mesohyl, which makes them able to either incorporate nitrogen from the water (via aerobic fixation) or to release nitrogen to the water column (via annamox) or both. Often, they are also net sources of nitrate and ammonium that facilitate local primary productivity and the general reef microbial loop. The majority of reef sponges belong to the class Demospongiae, most of which produce siliceous skeletons in such large amounts that make the whole reef ecosystem function as net silicon sink, even more important than diatom primary productivity (Maldonado et al. 2010).

A number of species (mainly belonging to the family Clionaidae) participate in limestone destruction (bioerosion) that may weaken reefs. The excavation process produces very fine sediments that fill crevices in the framework but may also lead to the smothering of other sessile reef organisms. Interestingly, the information to date suggests that many tropical reef sponges, and particularly the excavating ones, would tolerate and even be favored by the predicted scenarios of ocean warming, acidification, and coral decimation for the next 100 years. The general trend is that the abundance of reef sponges may be rising in areas with regressing coral covers (Bell et al. 2013). Yet local examples of sponge decline also occur. A 14-year census in the Panamanian Caribbean revealed the steady disappearance of the less common species $(51.3 \%$ ) and a $42.6 \%$ drop in the local sponge biomass (Wulff 2006). The 
causes of such local sponge declines remain unclear, but diseases emerge as a major factor of mortality for tropical sponge assemblages.

This section summarizes information for the best known reef systems, but many others known to occur still remain poorly investigated.

\section{$3 \quad$ Mangrove Sponge Aggregations}

Mangroves are tropical or subtropical coastal, intertidal plant communities dominated by certain species of trees that have specialized root systems allowing them to cope with anoxic mud substrata. Their distribution parallels that of coral reefs, except that they are more tolerant to temperature and salinity fluctuations, and therefore they extend between $25^{\circ} \mathrm{N}$ and $25^{\circ} \mathrm{S}$ latitude. Among the many species of mangrove trees, those belonging to the genus Rhizophora have stilt roots that provide stable substrates within a soft-mud environment where sessile organisms, such as sponges, hydroids, bivalves, polychaetes, barnacles, and tunicates, can attach. Although factors such as temperature, salinity stress, and limited water renewal influence the abundance of sessile invertebrates on the roots, their abundance and distribution is mostly determined by the tidal regime and the tolerance of the species to aerial exposure and solar radiation. Sponges, in particular, do not have protective shells and therefore have limited tolerance to low-tide exposure. This explains why early reports from Indo-Pacific mangroves earned them a reputation for supporting a poor sponge fauna because the large tidal ranges (approximately $1-3 \mathrm{~m}$ ) are too stressful. There are however exceptions, such as mangroves in certain marine lakes and along coastal islands in the Berau region of Indonesia (Becking et al. 2013). A total of 119 sponge species have been described from these habitats, some even tolerating unusually long air-exposure times.

In the Caribbean, the mean tidal range is much lower (about $15 \mathrm{~cm}$ ), which allows more sponge species to settle and survive on mangrove stilt roots and peat banks. Out of the 550 invertebrate and alga species found living as epibionts of mangle roots in the Caribbean (Guerra-Castro and Cruz-Motta 2014), sponges are estimated to contribute about $10-70 \%$ of the species richness on submerged roots (Diaz and Rützler 2009). Some of these Caribbean mangrove sponges, which are well adapted to live near the mean low tide mark (Fig. 3a), can also survive temporary exposure during very low spring tides (Rützler 1995), such as Lissodendoryx isodyctialis (Fig. 3a, f) Haliclona manglaris (Fig. 3b), and H. implexiformis (Fig. 3e). Up to 127 sponge species have been reported inhabiting mangrove roots in eight Caribbean countries (Belize, Colombia, Cuba, Guadalupe, Jamaica, Panama, Trinidad, and Venezuela), although most mangrove systems remain unexplored (Guerra-Castro and Cruz-Motta 2014). In Belize, where a number of mangrove forests have been studied (Rützler et al. 2000; Maldonado et al. 2010), Twin Cays, which is a mangrove island inside the barrier reef west of the field station on Carrie Bow 

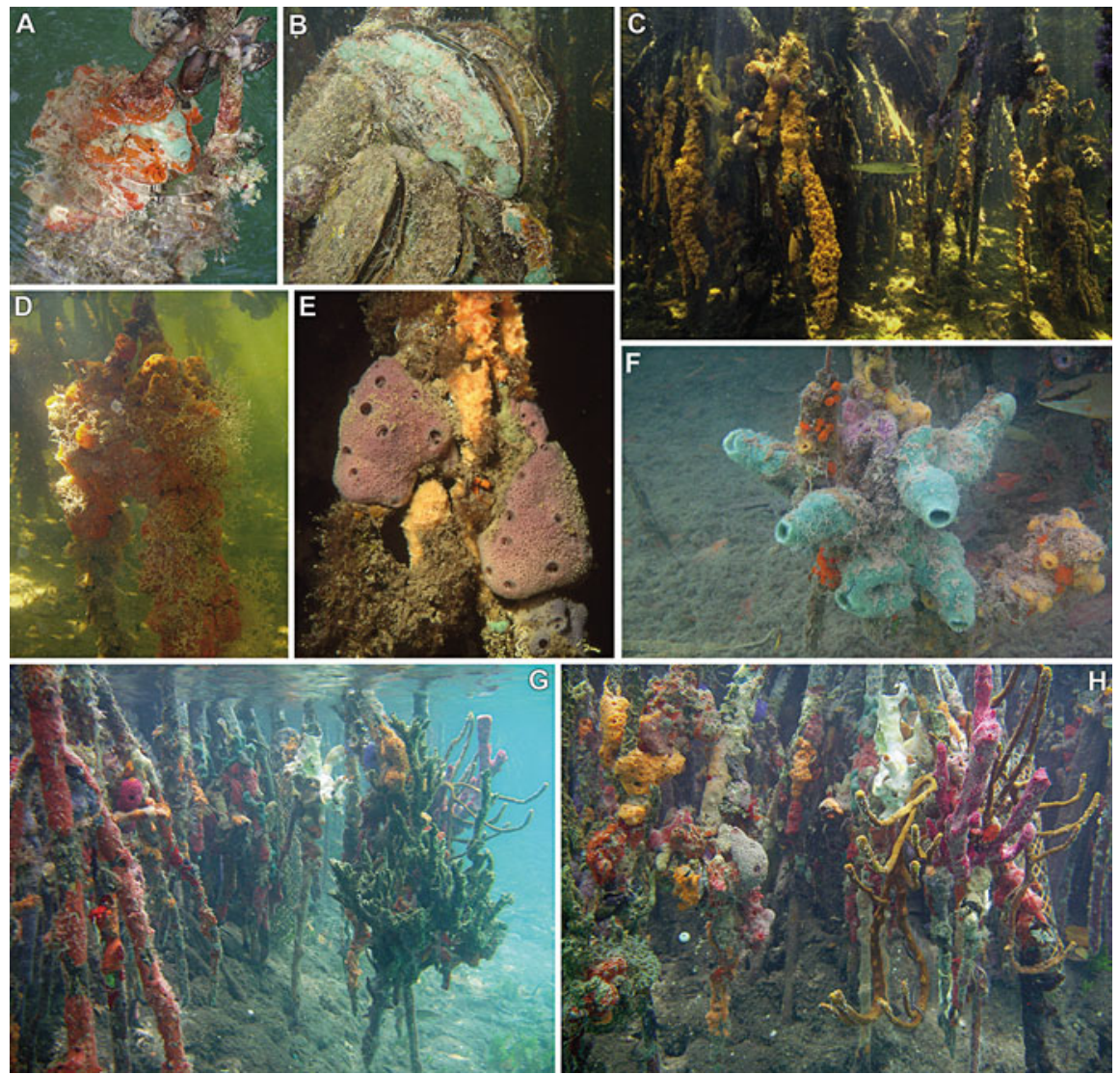

Fig. 3 Views of mangrove sponge aggregations. (A-F) Views of sponges on red-mangrove roots lining a Twin Cays canal. (A) Massive Tedania ignis (red) and Lissodendoryx isodictyalis (blue) growing on roots at the lower limit of low tide; (B) Haliclona manglaris (blue) growing on mangrove oysters, Isognomon alatus, while fully exposed to air during low tide; (C, D) roots almost entirely dominated by massive T. ignis in the "Sponge Haven" area of Twin Cays; (E) Root covered by massive Haliclona implexiformis (purple), thickly encrusting Scopalina ruetzleri (yellowish orange), and a small patch of $H$. manglaris (bright blue); (F) A typical combination of dominant sponge species on roots at Twin Cays: L. isodyctialis (blue), H. implexiformis (purple), and Halichondria magniconulosa (yellow), along with the bright orange tunicate Distaplia corolla. $(\mathbf{G}, \mathbf{H})$ Two general views of the very diverse sponge assemblage on roots in a Pelican Pond mangrove. Sponges seen are Mycale microsigmatosa, Mycale laxissima, Mycale laevis, S. ruetzleri, Iotrochota birotulata, Aplysina cf. cauliformis, Dysidea etheria, Chelonaplysilla sp., Desmapsamma anchorata, and Amphimedon compressa, among others

Cay, supports 57 sponge species (see Table 1 for most common species; Fig. 3a-f). The nearby mangrove ponds of the Pelican cays, only $16 \mathrm{~km}$ to the southwest, where the barrier reef is broken up and allows oceanic water to flush the lagoon, supports more than 147 species (Fig. $3 g-h$ ), according to a revision of the census in progress. 
Although mangrove specialist sponges do exist, such as Haliclona manglaris (Fig. 3b, e) that rarely grows in habitats other than mangrove, most of the sponge fauna in Caribbean mangroves consists of generalist species that, because of their resistance to desiccation, siltation, and salinity stress, are able to colonize this habitat from adjacent reefs and seagrass meadows (see Table 1 for examples of shared species). Nevertheless, these mangrove-colonizing generalists develop abundance patterns different from what they show in adjacent reefs and seagrasses; coupled with the presence of some mangrove specialists, this makes the sponge fauna of mangroves systems across the Caribbean globally distinct (Diaz 2012). Unlike coral reefs, where large tubular, vase, and ramose species dominate, mangroves are rich in thin crusts and thick massive sponges. Demosponges from the orders Poecilosclerida (Clathria, Tedania, Lissodendoryx, and Mycale) and Haplosclerida (Haliclona, Niphates) have a high diversity and dominate the mangrove sponge fauna (Fig. 3). When mangrove systems are altered by natural or man-induced disturbance (e.g., clear cutting and increased sediment in water) opportunistic species, such as Tedania ignis (Fig. 3c, d) and Clathria curacaoensis (senior synonym of C. schoenus), tend to increase in abundance over more mangrove-specialized species.

Significant spatial variability in species composition has been reported at four spatial scales within southern Caribbean mangroves: among roots, sites, localities, and regions. Yet since mangrove stilt roots can extend underwater by up to 2-3 m, the composition and abundance of sponge species also varies along the submerged length of the root. Collectively, these patterns suggest high regional and local $\beta$ diversity. Local colonization events and succession have been shown to be important factors explaining a large portion of the spatial variation in these communities. Competition for space and predation from asteroid echinoderms and fishes is also important in shaping the structure of mangrove sponge assemblages.

Accurate quantifications of mangrove sponge biomass are scarce. Estimates at Twin Cays mangrove islands (Belize) provided an average of $1.9 \pm 3.9 \mathrm{~L}$ of sponge $\mathrm{m}^{-2}$ (Table 1), a value that, although restricted to the small extension of the mangrove habitat, runs parallel to or even surpasses the biomass average of sponges living in adjacent patch reefs and seagrass meadows (Table 1). On the leeward sides of the islands, sponges are more abundant, covering $10-50 \%$ of the root surfaces, followed by sea anemones, ascidians, and algae. The bulk of biomass is typically provided by few, locally dominant species. For example, an assessment of total root coverage at four distinct sites in Bocas del Toro (Panama) revealed that the six most common sponge species out of the 65 identified species contributed $87-99 \%$ of the total coverage.

What ultimately favors sponges to aggregate at extremely high densities on some mangrove roots remains unclear, but physiological benefits could mediate such a sponge-mangrove-root association. Indeed, sponges growing on mangrove roots have been shown to incorporate DOM from the root (Ellison et al. 1996), possibly through unique sponge-associated microbes capable of processing mangrovederived DOM. Furthermore, an apparent transfer of sponge-fixed nitrogen has 
been detected on mangrove leaves, suggesting that the exchange of multiple organic compounds can take place between the sponges and the mangrove trees.

\section{Deep-Sea Astrophorid and Hexactinellid Grounds}

Dense aggregations of astrophorid demosponges and hexactinellids are common at lower shelf, bathyal, and/or abyssal depths. At the shallowest zones, these aggregations often also incorporate a mixture of other demosponges. In the Northern Hemisphere, these sponge aggregations are well known in the North Atlantic, within the $40^{\circ}-75^{\circ} \mathrm{N}$ latitude belt, a zone coincidental with elevated levels of dissolved nutrients and primary production in surface waters. The absence of continental margins in the equivalent $40^{\circ}-60^{\circ} \mathrm{S}$ latitude belt (Southern Ocean) has limited benthic research, leaving it unknown whether analogous bathyal and abyssal sponge aggregations occur, except on the Kerguelen Plateau.

In the North Atlantic, extensive "astrophorid sponge grounds" are found from the western Barents Sea along the Norwegian shelf to the Faroes, the Shetlands and the western banks, south of Iceland, along the Reykjanes Ridge, to southern Greenland, and in the northwest Atlantic along the continental shelf and slopes off Labrador and Newfoundland (Klitgaard and Tendal 2004; Murillo et al. 2012; Knudby et al. 2013; Beazley et al. 2015). These sponge grounds typically occur on gravel and coarse sand bottom and at depths from 150 to $1,700 \mathrm{~m}$. The fauna is dominated by large species of the genus Geodia (Fig. 4a), with additional astrophorids in the genera Stryphnus, Stelletta, and Thenea and the axinellid Phakellia (Table 2). The association is found over a vast geographic area, and depending on local conditions of topography, bottom type, and hydrography some variation in dominance of species, taxonomic composition, and densities occurs. This is most clearly seen in fjord areas, where the number of species lowers significantly when ascending to depths as shallow as $60-80 \mathrm{~m}$. On the Norwegian continental shelf, the combined density of the five most dominant sponge species, Geodia barretti, G. atlantica, G. macandrewii, G. phlegraei, and Stryphnus fortis peaks up to six individuals $\mathrm{m}^{-2}$, with an average value of $0.43 \pm 0.08$ individuals $\mathrm{m}^{-2}$ (Kutti et al. 2013). The first-mentioned three Geodia species together constitute more than $50 \%$ of the total sponge abundance, and individuals may exceed $1 \mathrm{~m}$ in diameter. At some sites of the Norwegian shelf, estimates of $G$. barretti wet biomass alone average $1.4 \mathrm{~kg}$ $\mathrm{m}^{-2}$ but can be as high as $45 \mathrm{~kg} \mathrm{~m}^{-2}$. Grounds in the same area may also be totally dominated by Stryphnus fortis, reaching a similar biomass per $\mathrm{m}^{-2}$ (Fig. 4b). Density of habitat forming sponges on the grounds in the northwest Atlantic ranges from 5 to 25 sponges $\mathrm{m}^{-2}$, with more than 15 sponges $\mathrm{m}^{-2}$ triggering a significant increase in the number of associated fauna (Beazley et al. 2015). Indeed, the astrophorid grounds are biodiversity hotspots (compared to non-sponge habitats) across the northern Atlantic, where sponges can constitute about $90 \%$ of the benthic biomass, excluding fishes (Klitgaard and Tendal 2004; Murillo et al. 2012). Such sponge biomasses are responsible for significant carbon and nitrogen cycling processes. For instance, average carbon consumption by $G$. barretti alone at the 

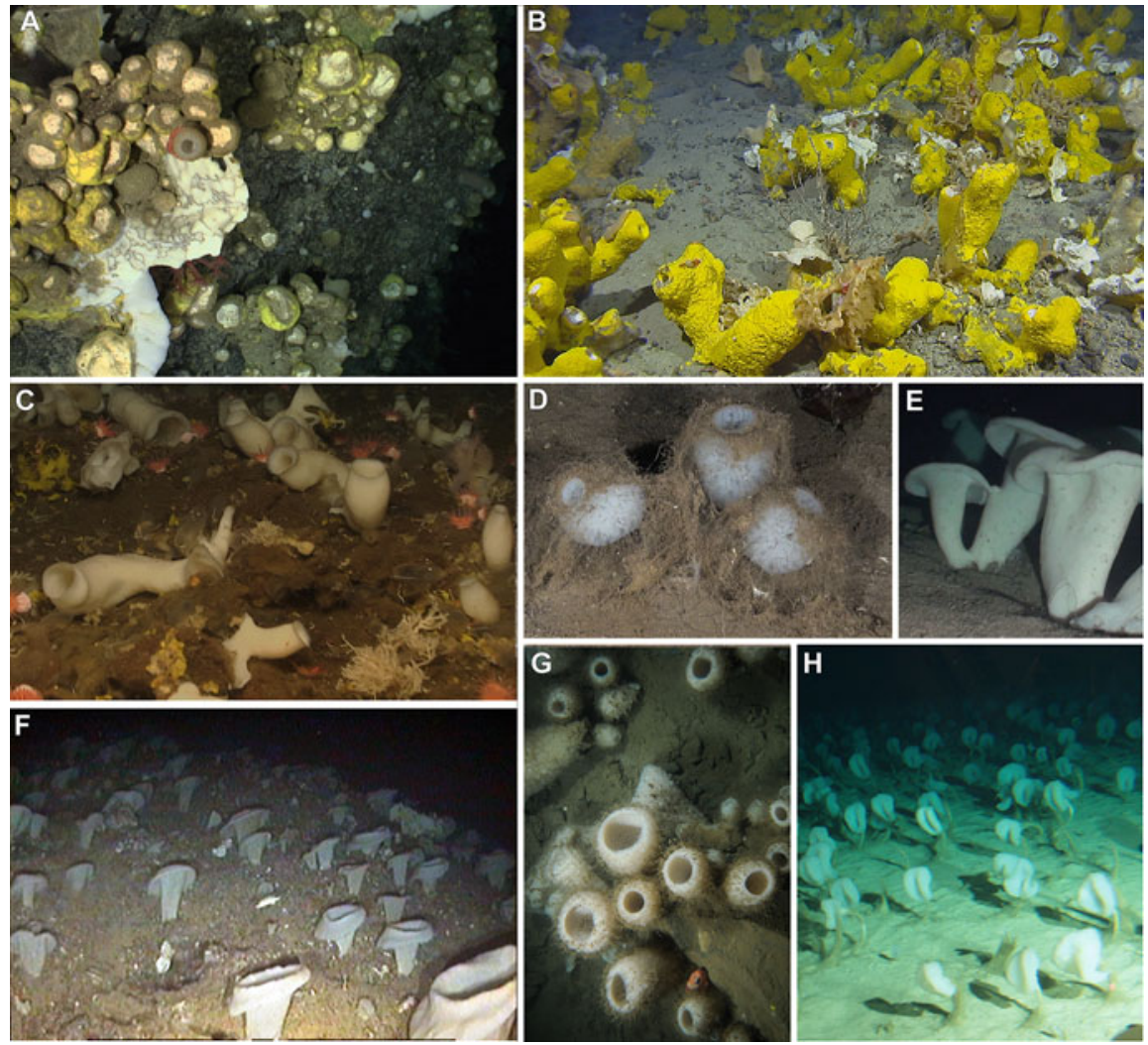

Fig. 4 Views of deep-sea astrophorid and hexactinellid sponge grounds. (A) Bathyal sponge ground at Flemish Cap (Canada), typically dominated by Geodia barretti and G. phlegraei, and with common occurrence of Stryphnus spp. (B) View of an aggregation dominated by Stryphnus fortis at the Norwegian deep shelf. In (A) and (B) grounds, the astrophorids are often covered by the yellow, encrusting sponge, Hexadella detritifera. (C) A dense aggregation of Trichasterina borealis and Schaudinnia rosea forming on a seamount at the Arctic Mid-Ocean Ridge. In between the hexactinellids, Geodia hentscheli, G. parva, and Thenea valdiviae occur intermingled, collectively resulting in a dense sponge coverage and favouring a substantial spicule mat on the bottom. (D) View of aggregated Pheronema carpenteri on soft bathyal bottoms in the North Atlantic. (E, F) View of Asconema setubalense fields on bathyal seamounts at the Alboran Sea (Mediterranean) and around the Canary Islands (North Atlantic). Note a small individual in (E) formed by budding from the base of a large adjacent individual. (G) View of a bathyal aggregation of Vazella pourtalesi on the north-western continental margin of the Atlantic. (H) Views of an aggregation of the parachutelike Sericolophus hawaiicus at the Kona slope (Hawaii, USA), showing all individuals oriented in the direction of the prevailing current for facilitated suspension feeding

northern Norwegian shelf is estimated at $200 \mathrm{mg} \mathrm{C} \mathrm{m}^{-2} \mathrm{~d}^{-1}$, ranging between 30 and $400 \mathrm{mg} \mathrm{C} \mathrm{m}^{-2} \mathrm{~d}^{-1}$. It means that the shelf population of $G$. barretti can filter approximately 250 million $\mathrm{m}^{3}$ of water and consume $60 \mathrm{t}$ of carbon daily (Kutti et al. 2013). The Geodia grounds extend into the Arctic, from north of Spitzbergen to the Fram Strait and along the East Greenland shelf edge into the Denmark Strait and 
Table 2 Most common sponge species in the North Atlantic deep-sea aggregations. Main habitat builders are referred to as "XXX", common accompanying species as "XX", less common but yet frequent species as "X". Stryphnus ponderosus has often been reported in the literature on boreal sponge grounds, but most records probably correspond to $S$. fortis

\begin{tabular}{|c|c|c|c|c|}
\hline Sponge species & $\begin{array}{l}\text { Boreal Geodia } \\
\text { grounds }\end{array}$ & $\begin{array}{l}\text { Arctic Geodia } \\
\text { grounds }\end{array}$ & $\begin{array}{l}\text { Thenea } \\
\text { grounds }\end{array}$ & $\begin{array}{l}\text { Thenea-Radiella } \\
\text { grounds }\end{array}$ \\
\hline Asconema foliata & $\mathrm{X}$ & $\mathrm{XXX}$ & & \\
\hline $\begin{array}{l}\text { Caulophacus } \\
\text { arcticus }\end{array}$ & & & & XXX \\
\hline Cladorhiza gelida & & $\mathrm{X}$ & & $\mathrm{XXX}$ \\
\hline Forcepia topsenti & & & & $\mathrm{XXX}$ \\
\hline Geodia atlantica & XXX & & & \\
\hline Geodia barretti & $\mathrm{XXX}$ & $X$ & $\mathrm{X}$ & \\
\hline Geodia hentscheli & & XXX & $\mathrm{X}$ & \\
\hline $\begin{array}{l}\text { Geodia } \\
\text { macandrewii }\end{array}$ & $\mathrm{XXX}$ & $\mathrm{XX}$ & & \\
\hline Geodia parva & $\mathrm{X}$ & $\mathrm{XXX}$ & $X$ & \\
\hline Geodia phlegraei & XXX & $\mathrm{X}$ & & \\
\hline $\begin{array}{l}\text { Hymedesmia } \\
\text { stylata }\end{array}$ & & & & XXX \\
\hline Phakellia robusta & $\mathrm{XXX}$ & $X$ & & \\
\hline $\begin{array}{l}\text { Phakellia } \\
\text { ventilabrum }\end{array}$ & XXX & $\mathrm{XX}$ & & \\
\hline Radiella sol & & $\mathrm{X}$ & & XXX \\
\hline Schaudinnia rosea & & $\mathrm{XXX}$ & $\mathrm{X}$ & \\
\hline $\begin{array}{l}\text { Scyphidium } \\
\text { septentrionale }\end{array}$ & & $\mathrm{XX}$ & & \\
\hline Stelletta normani & XXX & $\mathrm{X}$ & & \\
\hline $\begin{array}{l}\text { Stelletta } \\
\text { rhaphidophora }\end{array}$ & & $\mathrm{XXX}$ & $\mathrm{X}$ & \\
\hline Stryphnus fortis & $X$ & & & \\
\hline Sycon abyssale & & & & XXX \\
\hline $\begin{array}{l}\text { Tentorium } \\
\text { semisuberites }\end{array}$ & $X$ & $\mathrm{X}$ & & XXX \\
\hline Thenea abyssorum & & $\mathrm{X}$ & & XXX \\
\hline Thenea levis & $\mathrm{XX}$ & & $\mathrm{XX}$ & \\
\hline Thenea muricata & $\mathrm{XX}$ & $\mathrm{X}$ & $\mathrm{XXX}$ & \\
\hline Thenea valdiviae & $\mathrm{X}$ & $\mathrm{XX}$ & $\mathrm{XXX}$ & \\
\hline $\begin{array}{l}\text { Trichasterina } \\
\text { borealis }\end{array}$ & & $\mathrm{X}$ & & \\
\hline
\end{tabular}

north of Iceland in the east, and in the Davis Strait and into the Canadian Archipelago in the west. There the sponge fauna also includes species of the hexactinellid genera Asconema, Trichasterina, Schaudinnia, and Scyphidium, along with an abundance of the astrophorids Stelletta and Thenea (Fig. 4c, Table 2). 
Thenea grounds occur in deep fjords in Norway, Iceland, and East Greenland, as well as along continental shelves and on seamounts in the northeast Atlantic and the Arctic at $100-900 \mathrm{~m}$ depth. The preferred substratum is mud, often charged with large amounts of released sponge spicules that form mat-like structures. Thenea muricata is the most common species (Table 2), with a body size reaching up to $50 \mathrm{~cm}$ diameter. Below 2,000 $\mathrm{m}$ depth in the basins of the Greenland, Iceland, and Norwegian Seas, grounds of Thenea abyssorum and the hadromerid Radiella sol occur, including spirophorid species of Craniella at combined densities of up to 20-24 individuals $\mathrm{m}^{-2}$. Dwarfed species of the genera Radiella, Tentorium, Forcepia, and Hymedesmia also occur, together with a constant presence of smaller calcareous sponge species (Table 2). Abyssal populations of T. abyssorum, Tentorium semisuberites, and Craniella spp. account for about $90 \%$ of sessile biomass and are estimated to process $1-6 \mathrm{mg} \mathrm{C} \mathrm{m}^{-2} \mathrm{~d}^{-1}$, with a substantial coupled oxygen demand (Witte and Graf 1996). Thus, these sponge grounds have a significant role in the deep-sea turnover of organic carbon, although their flux is one to two orders of magnitude lower than those in Geodia grounds. Thenea spp. reproduce both sexually and asexually by budding, which could facilitate aggregated growth. The growth of oocytes in the abyssal populations of T. abyssorum is rapid and synchronous, triggered by a seasonal input of particulate organic matter from the photic ocean (Witte 1996). These patterns suggest that sexual reproduction and other metabolic activities in abyssal sponge grounds may be markedly connected to events and cycles of the photic ocean.

At lower latitudes than the high-production belts described above, several different types of aggregation of deep-sea astrophorid demosponges have been described. In the eastern North Atlantic and in the Mediterranean Sea, the astrophorids Pachastrella monilifera and Poecillastra compressa have been reported to reach densities of up to $10 \pm 0.7$ individuals $\mathrm{m}^{-2}$ and a wet weight biomass of up to $0.315 \mathrm{~kg} \mathrm{~m}^{-2}$. The axinellid Phakellia ventilabrum may also contribute to these aggregations with average densities of up to $0.27 \pm 0.01$ individuals $\mathrm{m}^{-2}$, as has been recorded for the Cantabrian Sea.

Also at temperate latitudes, hexactinellids may form dense sponge aggregations. However, they differ from the astrophorid demosponges in that they typically form monospecific grounds. The hexactinellid Pheronema carpenteri probably forms the most extensive sponge aggregation, occurring from south of Iceland and west of Scotland, across the Porcupine Seabight, Azores, northern Spain, Portugal, Canary Islands, and off Morocco at $800-1,350 \mathrm{~m}$ depth. The substrate is mud with large amounts of sponge spicules often forming mats. The sponges are nest shaped, up to $25 \mathrm{~cm}$ high and $30 \mathrm{~cm}$ across, and can be more than $200 \mathrm{~g}$ in wet weight. They are anchored in the mud by rooting tufts of long spicules (Fig. 4d), with aggregations of up to 475 individuals $1,000 \mathrm{~m}^{-2}$, and peak abundances and wet weight biomass up to six individuals $\mathrm{m}^{-2}$ (average 1.5 individuals $\mathrm{m}^{-2}$ ) and $1.1 \mathrm{~kg} \mathrm{~m}^{-2}$ (average $372 \mathrm{~g} \mathrm{~m}^{-2}$ ), respectively (Rice et al. 1990). Sexual reproduction remains unknown, with budding from the lower part of the sponge suggested to give rise to clumps of individuals. 
Three other kinds of hexactinellid-dominated sponge grounds, but of smaller spatial extent, are known from several areas of the North Atlantic. Off the Canary Islands, off Portugal, and at the Alboran Sea (Mediterranean Sea), small fields of the large (up to $1 \mathrm{~m}$ tall) vase-shaped Asconema setubalense have been found on seamounts at bathyal depths (Fig. 4e, f). Details of the extension, biomass, and densities have not been obtained, but clumps of up to five individuals $\mathrm{m}^{-2}$ have been recorded, with average density of about 0.5 individuals $\mathrm{m}^{-2}$ at the densest areas of the aggregation. On the eastern Scotian Shelf off Nova Scotia, Vazella pourtalesi, a barrel-shaped sponge up to $30 \mathrm{~cm}$ (commonly known as "Russian hats") forms large monospecific aggregations with densities of up to eight individuals $\mathrm{m}^{-2}$ on muds with sponge spicules at 100-600 m depth (Fig. 4g). It is a rare species only known elsewhere from the Gulf of Mexico and the Azores where it has been reported at low densities. Similarly, the cup-shaped up to $40 \mathrm{~cm}$ high Nodastrella asconemaoida forms aggregations with densities up to six individuals $\mathrm{m}^{-2}$ at $560-630 \mathrm{~m}$ depth on cold-water coral reefs on Rockall Bank west of Ireland. It is a rare species, with only a few specimens known from off Florida and possibly from the Mid-Atlantic Ridge (Dohrmann et al. 2012).

At tropical latitudes, dense, monospecific aggregations of hexactinellids have also been described in the bathyal zone. Sericolophus hawaiicus forms a $300 \mathrm{~km}-$ long population that encircles the island of Kona (Hawaii) at 350-450 m depth (Fig. 4h), forming a $100 \mathrm{~m}$-wide belt on the slope. The upper bathymetric limit of the sponge population is imposed by the presence of the $10{ }^{\circ} \mathrm{C}$ permanent thermocline, while the lower depth limit is set by the occurrence of a minimum oxygen layer. The sponge is about $50 \mathrm{~cm}$ in total height, consisting of a $20 \mathrm{~cm}$-wide cup-like body with an outward-folded margin that becomes inflated as a parachute by the horizontal currents. The body is anchored to the fine sand bottom by a flexible stalk consisting of a bunch of up to $50 \mathrm{~cm}$-long parallel spicules. The maximum sponge density in central areas of the population is $10-14$ individuals $\mathrm{m}^{-2}$ and $0-2$ individuals $\mathrm{m}^{-2}$ near the edges of the band, with the overall density averaging 2.3 individuals $\mathrm{m}^{-2}$. Nothing is known about the reproduction, although small juveniles are often seen adjacent to the stalk of the adults. The dense sponge aggregation appears to feed not only on deep-sea bacteria but also on abundant cyanobacteria brought from the photic zone by a down-slope current. These sponges, with their parachute-like body and a stalk of twisting spicules that allows reorientation to shifts in the prevailing current, are particularly suited to capture the suspended food provided by horizontal flows. The sponge aggregation is estimated to consume about $55 \mathrm{mg} \mathrm{C}$ and $7.3 \mathrm{mg} \mathrm{N}$ $\mathrm{m}^{-2} \mathrm{~d}^{-1}$, being a significant regional player in the deep-sea microbial food web (Pile and Young 2006). Likewise, the population is estimated to contain a silica standing stock of about $2.7 \mathrm{t}$ per linear $\mathrm{km}$ of sponge band, becoming a massive regional silicon sink (Maldonado et al. 2005).

At the abyssal plains, low-density fields of scattered hexactinellids may extend over vast areas. For instance, extensive fields consisting of two flat, mat-like species, Bathydorus laniger (21 cm diameter on average) and Docosaccus maculatus $(12 \mathrm{~cm}$ diameter on average), and the stalked Hyalonema bianchoratum occur at 4,000 $\mathrm{m}$ in the northeast Pacific, $220 \mathrm{~km}$ west of the central California coast. Over the years, 
average individual size and density in these sponge fields fluctuate as a result of shifts in the input of POC into the benthic boundary layer. The variability of POC inputs may range over two orders of magnitude, from $0.22 \mathrm{mg} \mathrm{C} \mathrm{m}^{-2} \mathrm{~d}^{-1}$ during years of low primary productivity in the overlying photic ocean to $20 \mathrm{mg} \mathrm{C} \mathrm{m}^{-2} \mathrm{~d}^{-1}$ or more during years of high productivity. An increase in size and sponge density appears to occur with a time lag of 13 months after arrival of the POC pulse to the benthic layer. Average density of the two mat-like species was about $91.2 \pm 12.4$ individuals ha ${ }^{-1}$ from 1989 to 2006 . The greatest density was 363.5 individuals ha ${ }^{-1}$ in 2004. Nevertheless, although moderate seasonal POC inputs appear to stimulate sponge recruitment, large food influxes modify drastically the community structure, increasing the density of a few species, while often decreasing the overall diversity. Between 2006 and 2012, two major inputs of organic carbon in the form of phytodetritus (in 2006) and carbon-rich salps (in 2012) occurred, followed by a community shift from a sponge-dominated community to a mobile, detritus-feeding, holothurian-dominated community. In parallel to the decline of filter-feeding sponges, carnivorous sponges increased (Kuhnz et al. 2014). These dynamics provide strong evidence that even abyssal sponge aggregations can be significantly impacted by natural and man-driven changes taking place in the photic ocean and that the concept of slow growing and long lived for abyssal hexactinellids may not be universal.

This section summarizes information for the best studied astrophorid and hexactinellid aggregations but others, still poorly investigated, are known, such as the bathyal aggregations of Aphrocallistes beatrix around the Canary Islands, the Geodia spp. grounds in the North Pacific, the Monoraphis chuni grounds off New Caledonia, the Thenea spp. grounds in the Indian Ocean, and the Euplectella fields in the Sagami Bay off Japan. For virtually all aggregations described herein (but see Beazley et al. 2013, 2015; Knudby et al. 2013) how the reproductive biology, growth rates, longevity, and the environmental conditions (food supply, hydrography, seafloor traits, etc.) contribute to develop and maintain the aggregation of the habitatforming species remain poorly investigated or completely unaddressed.

\section{$5 \quad$ Glass Sponge Reefs}

As summarized in the previous section, hexactinellid sponge aggregations occur at bathyal and abyssal depths worldwide, but those in the form of biohermal reefs are exceptional. Biohermal sponge reefs were only known from the fossil record in mid-Jurassic to early-Cretaceous seas (Ghiold 1991; Wiedenmayer 1994), until to everyone's surprise, analogous hexactinellid reefs were discovered alive (Conway et al. 1991, 2005; Krautter et al. 2001) on the western Canadian continental shelf in the 1980s (Fig. 5a-b). In water depths from 90 to 240 m massive framework reefs are built by sponges of the order Hexactinosida, particularly by the species Aphrocallistes vastus, Heterochone calyx, and Farrea occa, all of which have secondary silicification to fuse their spicules into a rigid 3D silica framework (Fig. $5 \mathrm{c}-\mathrm{f}$ ). The young sponges attach to the skeletons of dead sponges leading to biohermal growth. Other hexactinellid species from the order Lyssacinosida are 
found among the reefs where the reef is less dense. The reefs may be up to $25 \mathrm{~m}$ in height and up to 9,000 years old and mantle hundreds of $\mathrm{km}^{2}$ of the seabed (Conway et al. 2005). Sponge reefs in the Strait of Georgia occur in clumps $35-70 \mathrm{~m}$ in diameter and, within clumps, individual sponges usually have several oscula (filtration units). Because the base of individuals is often hard to discern, reef density is gauged by oscula density (Fig. 5d). Densities of oscula are $23-46 \mathrm{~m}^{-2}$ and each sponge osculum may be $15-40 \mathrm{~cm}$ high. It is calculated that living sponge biomass (skeleton and tissue) in the living portion of three well-studied reefs in this area averages $17-26 \mathrm{~kg} \mathrm{~m}^{-3}$, with approximately $20 \%$ being organic tissue and $80 \%$ forming the siliceous skeleton.

Glass sponges are long lived, with growth rates up to $6 \mathrm{~cm} \mathrm{yr}^{-1}$ (Leys and Lauzon 1998) and a projected age of 220 years for $1 \mathrm{~m}$ large individuals. Those growth rates are very similar to estimates made for reef-forming sponges $\left(1-9 \mathrm{~cm} \mathrm{yr}^{-1}\right)$ from images captured in sequential years (Kahn et al. 2016). Both of these North-Pacific estimates are an order of magnitude higher than one made by dating the silica skeleton of a single dried specimen of Rosella racovitzae collected from Antarctica, which showed a growth rate of $2 \mathrm{~mm} \mathrm{yr}^{-1}$ and an estimated age of 440 years (Fallon et al. 2010). The faster growth rate of reef sponges may be an adaptation to outgrow sediment deposition in the siliciclastic reef environment.

Glass reef sponges filter almost continuously, and the density of oscula in reefs means that the sheer volume of water filtered by sponge reefs is astounding. Each osculum filters at a rate of $1-3 \mathrm{~cm} \mathrm{~s}^{-1}$, and for the range of sizes of oscula measured $\left(15-40 \mathrm{~cm}^{2}\right)$ the filtration rate is $1.3-10.3 \mathrm{~m}^{3} \mathrm{~d}^{-1}$ per osculum (Kahn et al. 2015). The grazing (filtration) rate of sponge reefs in the Strait of Georgia was estimated to be $85-198 \mathrm{~m}^{3} \mathrm{~m}^{-2} \mathrm{~d}^{-1}$, more than twice the rate of the next most intense suspension feeding community known, mussel beds in shallow bays (Kahn et al. 2015). The sponges daily clear the equivalent of the entire water column above them $(170 \mathrm{~m})$ of all bacteria, while new bacteria are supplied by prevailing currents, but exactly what the source is (whether from sinking of marine snow or from deep water brought in onto the shelf) is still to be determined. Sponge filtration not only clears the water column of vast numbers of bacteria, but it also recycles wastes to the water in the form of ammonium and $\mathrm{CO}_{2}$. Additionally, reef sponges excrete particulate wastes as 50-60 $\mu \mathrm{m}$ aggregates that could be eaten by deposit feeders, but such a putative fueling of the food chain awaits to be empirically proved. These heavily silicified sponges also take up an important amount of silicate from the water column to form the skeletal framework. Silicon uptake rates are estimated to be one to two orders of magnitude lower $(3.5 \mathrm{mmol}$ $\mathrm{Si} \mathrm{m}^{-2} \mathrm{~d}^{-1}$ ) than those of other silicifiers, such as diatoms, but, over the long lifetime of these sponges, it leads to substantial accumulation of silicon in the skeletons. In the living portion of three well-studied reefs in the Strait of Georgia, the biogenic silica standing stock averages $7-12 \mathrm{~kg} \mathrm{~m}^{-2}$ (Chu et al. 2011). Since up to $25 \mathrm{~m}$ of biohermal structure may lie below the surface, a lot more silica is locked below ground, and therefore sponge reefs form a regionally important silicon sink.

Glass sponges reproduce sexually, with spermatocysts and embryos being found in winter months, and juveniles less than $5 \mathrm{~cm}$ high being common on skeletons of dead sponges (Kahn et al. 2016). Genetic studies show high gene flow within and 
A
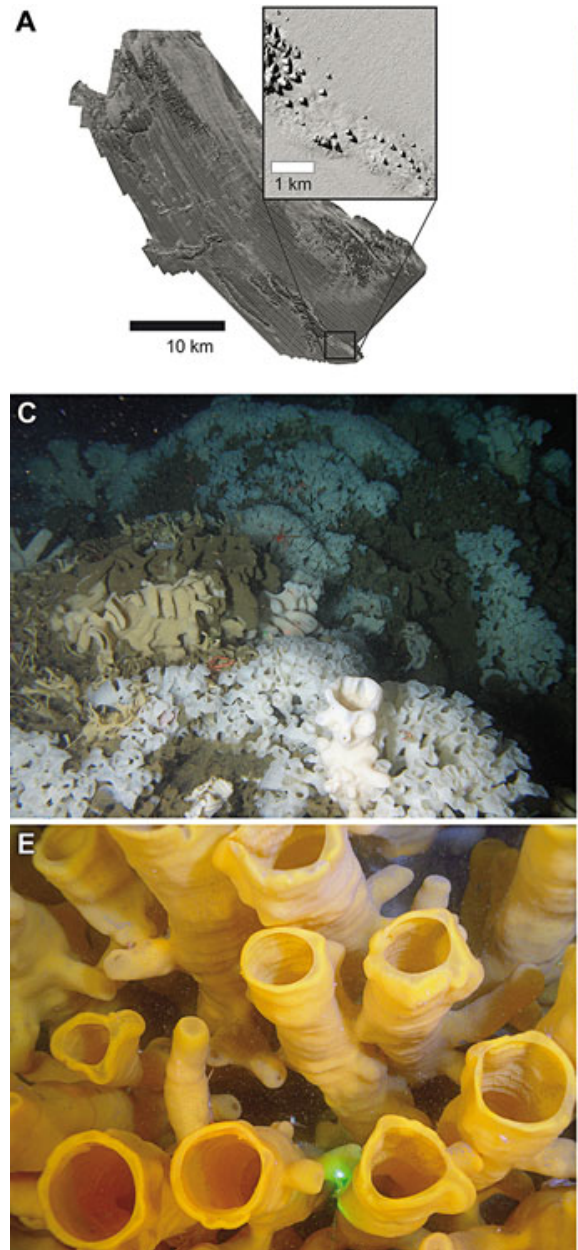
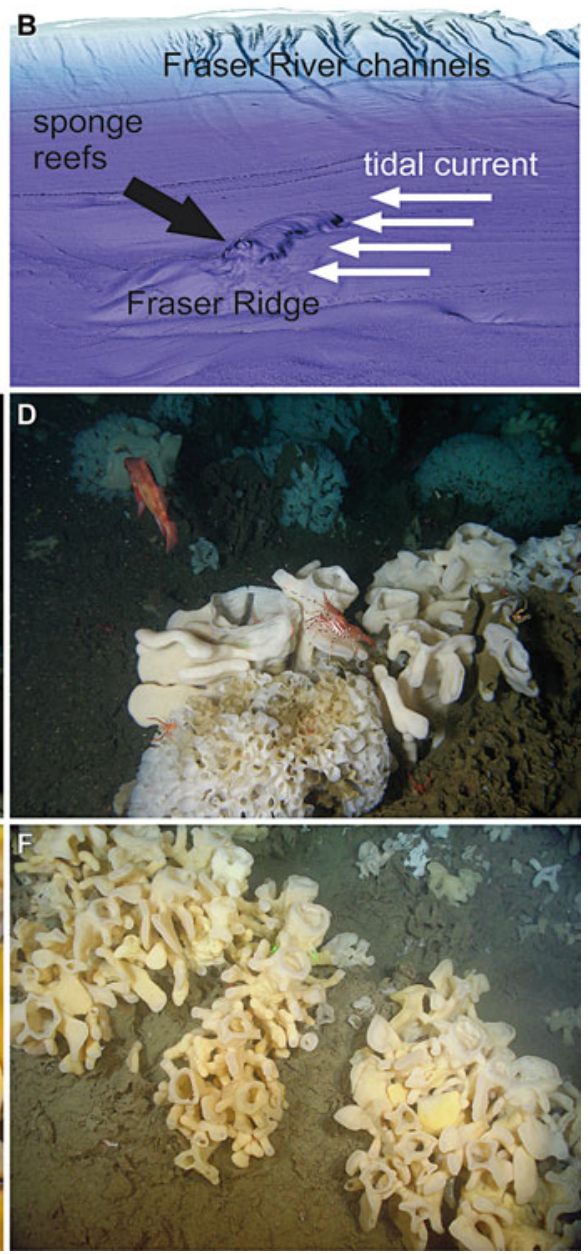

Fig. 5 Views of glass sponge reefs. (A, B) 3-D digital models created using multibeam data show the location and shape of glass sponge reef formations: (A) A chain of sponge reefs sits on a rough glacial seabed at the south end of the very large reef complex in Hecate Strait; (B) Fraser Ridge reef, very close to the channels of the Fraser River in the Strait of Georgia (SoG). (C) General view of a reef in Hecate Strait, a substantial component of which is Farrea occa (white) with individuals of Aphrocallistes vastus and Heterochone calyx often growing out of it. Red galatheid crustaceans are frequent inhabitants of the $F$. occa clumps. (D) Detail of clumps of $F$. occa and $H$. calyx, with crustacean and fish fauna in Hecate Strait. (E, F) Views of the Fraser Ridge Reef, showing oscula tubes of H. calyx (E) A. vastus (F) both characterized by lateral projections, which can result in the formation of new oscula

across the Strait of Georgia but not with glass sponges on the west side of Vancouver Island (Brown 2015). Sponges adjacent to one another in a clump are also genetically distinct. Therefore, reef sponge larvae are not necessarily long lived, but the flow regime that feeds the reefs also manages to disperse larvae well. 
Reef initiation is dependent on the long-term stability and relict nature of the deep shelf seafloor where coarse glacial deposits occur. Organic rich, mainly biogenic flocs (marine snow) and resuspended shelf sediments delivered by tidal currents (Fig. 5b) cement gaps and interstices in the reef surface. The reefs form large aggregations and develop into clusters with diverse forms, such as bioherms, ridges, and sheets or meadows that coalesce as the reefs form even larger complexes over millennia. It is thought that reefs develop in response to the ambient seabed currents and the availability of glacial substrate. Reefs may develop in areas of elevated suspended sediment concentration, such as at river deltas, but in all cases reef initiation requires a nondepositional seabed. This is somewhat contradictory and suggests a finely balanced system where sediment is required in order to provide the reef matrix, but too much sediment will smother the filter feeding sponges. Laboratory experiments showed that whereas the lyssacine glass sponge Rhabdocalyptus dawsoni arrests its filtration when sediment concentrations reach $11 \mathrm{mg} \mathrm{L}^{-1}$, the reef forming Aphrocallistes vastus is more tolerant and only arrests filtration at sediment concentrations of $35 \mathrm{mg} \mathrm{L}^{-1}$ (Tompkins-MacDonald and Leys 2008), which is significantly higher than the normal concentrations of suspended solids measured at the Fraser Ridge reef, $8.25 \mathrm{mg} \mathrm{L}^{-1}$.

The reefs may have developed preferentially in the Pacific because of the rich hexactinosidan sponge fauna in this region and are probably found in shallow waters in the Pacific because of relatively high silicate levels which do not normally occur in shelf depths elsewhere. Other factors that correlate with dense aggregations of glass sponges in shallow waters are low temperatures (below $12{ }^{\circ} \mathrm{C}$ ), low light, and high food availability.

In functional terms, the accumulative $3 \mathrm{D}$ growth of reef sponges leads to complex habitat formation. The biohermal topography provides shelters and smooths the local hydrodynamic patterns, while the biological activity of sponges increases the exchange of energy and matter between the water column and the benthos, all of which favors benthic biodiversity. Fish, crustaceans (Fig. 5c), nudibranchs, and infaunal polychaetes are all more abundant in reef habitats than in nonreef areas. These unique hexactinellid sponge reefs are vulnerable habitats and raise important conservation concerns.

\section{$6 \quad$ Lithistid Aggregations}

The "lithistids" are demosponges of diverse phylogenetic affinity but which are characterized by the common possession of hypersilicified desma spicules. The desmas interlock to form a rigid, massive silica skeleton that renders these sponges stony. Lithistids were present in the Cambrian ( $>540$ mya) forming dense assemblages in reefs that thrived through the Paleozoic ( $>254$ mya). A second major radiation and diversification took place in the Mesozoic, particularly from the late Jurassic (163-145 mya) through most of the Cretaceous (145-65 mya), when impressive "silica reefs" built by lithistids and hexactinellids (see Sect. extant glass sponge reefs) developed on continental shelves. These sponge reefs started 
to decline in the late Cretaceous (93-65 mya) and progressively disappeared through the lower Tertiary (65-23 mya). Present-day lithistids are considered to be remnants of that Mesozoic fauna, some taxa partially or totally having lost their rigid desma skeletons. During the Cretaceous (144-65 mya) over 150 reef-building genera were known. Today only 46 living genera are known, many of which only have one or two living representatives. They mostly occur in temperate and tropical latitudes; only one species is known from a polar region (Kelly 2007). They typically occupy deep habitats such as shelf breaks, steep slopes, seamounts, hydrothermal vents, and volcanic fields, but in some locations they are also common in shallow caves.

Two significant regional faunas of lithistids are known worldwide: the slope and continental shelf fauna of the tropical and subtropical Atlantic (Pomponi et al. 2001; this work) and the southwest Pacific seamount fauna including that of the Norfolk Ridge south of New Caledonia (Lévi 1991) and New Zealand (Kelly 2007; Kelly et al. 2007). In both regions lithistids dominate the fauna (along with hexactinellids), but the structure and taxonomic composition of the communities differ. In the tropical western Atlantic, lithistids form dense, low diversity communities dominated by species of genera Discodermia and Corallistes on vertical faces of shelf margins or old horizontal carbonate shelf reefs. Equivalent lithistid assemblages, but probably most important in terms of biomass, have recently been discovered on seamounts in the temperate eastern Atlantic (Fig. 6a-c). The seamount system of the Norfolk Ridge and New Caledonia harbors a much richer, unique lithistid fauna that appears largely unchanged from the Mesozoic, about 60-70 mya (Lévi 1991). These sponges dominate the benthic seamount macrofauna, being the only area in the modern ocean where the lithistid assemblages rival in taxonomic diversity with those from the Mesozoic. An important component of this fauna has been described from New Zealand and surrounding areas (Kelly 2007), with abundant populations at Wanganella and Pandora Banks, Three Kings Ridge, outer Bay of Plenty (Fig. 6d) and southern Kermadec Ridge, and North Taranaki Bight.

Although lithistids were significant members of Paleozoic and Jurassic reefs, they appeared unable to develop analogous aggregations in the modern ocean. This view has been challenged by the discovery of a monospecific reef-like formation around the top of a deep seamount at $800 \mathrm{~m}$ in the Mediterranean Sea (Maldonado et al. 2015). Individuals of the foliose species Leiodermatium pfeifferae, which grows as erect, contorted, $0.3-0.9 \mathrm{~cm}$ thick plates, up to about $80 \mathrm{~cm}$ in height, and $100 \mathrm{~cm}$ in width (Fig. 6e), occur at high densities, becoming intertwined. The massive lithistid skeletons neither disaggregate nor easily dissolve after sponge death, persisting as an available substrate for new lithistid individuals to recruit. The accretive, clumped growth produces sponge mounds on the seabed (Fig. 6f), conservatively estimated to reach a maximum height of about $180 \mathrm{~cm}$, but being on average at a height of $114 \pm 35 \mathrm{~cm}$. Because of the superimposing and intertwined nature of the aggregation, density is difficult to accurately estimate and tentative counts at the top layer of the formation indicate from 1 to about 16 individuals $\mathrm{m}^{-2}$, with sponges covering from $5 \%$ to virtually $100 \%$ of the seabed, and averaging about $41.6 \pm 29.5 \%$ cover. Such a dense and complex 3D "reef-like" aggregation attracts a diverse vagile fauna dominated by fish and macroinvertebrates. 

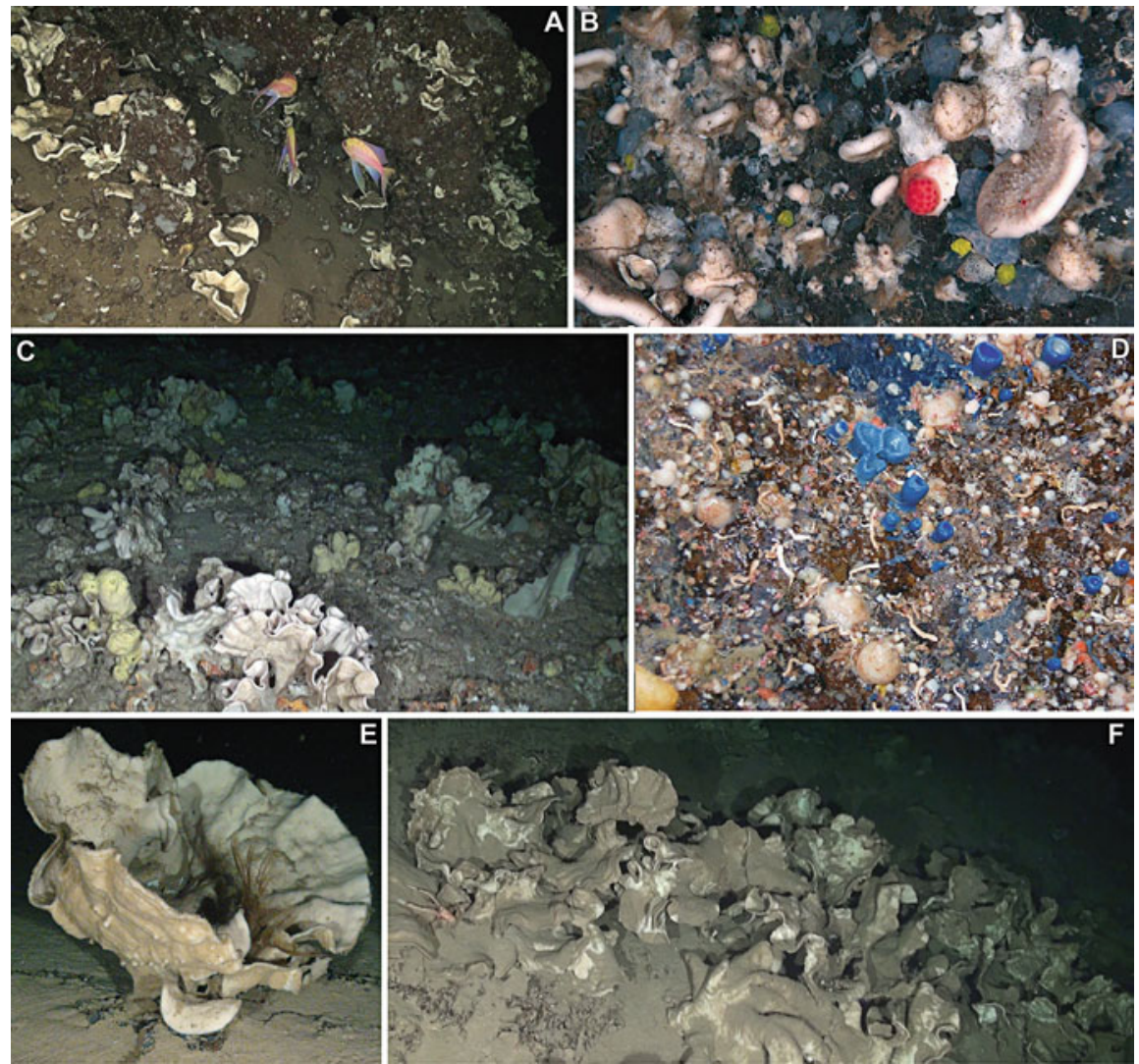

Fig. 6 Views of lithistid aggregations. Lithistid aggregations. (A, B) Assemblages of lithistid sponges dominated by corallistids recently discovered at seamounts around the Canary Islands (Eastern North Atlantic, Spain). (C) View of a sponge aggregation dominated by lithistids of the genera Corallistes, Macandrewia, Neophrissospongia, and Discodermia at the Gorringe Bank (Eastern North Atlantic, Portugal). Often, large astrophid demosponges in the genera Characella (covered by the yellow encrusting sponge Hexadella detritifera) and Pachastrella and haplosclerids in the genus Petrosia also occur. (D) Lithistid sponges on the surface of a boulder at $160 \mathrm{~m}$, Rungapapa Knoll, Bay of Plenty, New Zealand. Bright blue cup sponges are immature specimens of Reidispongia coerulea, cream knobs are Macandrewia spinifoliata. (E, F) View of an isolated individual of Leiodermatium pfeifferae and view of a small patch of the impressive reef-like aggregation formed by this species around the apex of the "Stone Sponge Seamount" in the Balearic Sea (Mediterranean), respectively

The particular circumstances that have favored the dense reef-like aggregation of L. pfeifferae at one particular seamount, but not on other adjacent seamounts where the species has also been recorded, remain unclear. At $800 \mathrm{~m}$ depth, silicate concentration (averaging annually $8.50 \pm 0.6 \mu \mathrm{M}$ ) and inputs of particulate food are only modest. As many other lithistids, L. pfeifferae is able to cope with intense siltation, promoting the accumulation of sediment on its inhalant layer. It is 
hypothesized that the sediment deposits, rich in organic content derived from decaying diatoms and other phytoplankton, could be used as both a medium to culture bacteria from which the sponges would subsequently feed and potentially a pathway to reuse silicate released from the dissolution of the accumulated diatom frustules.

In general, lithistids occupy a similar ecological niche to other deep-water sponges and are renowned for their associations with fungal and bacterial symbionts, many of which are the source of rich bioactive metabolites in these sponges. Factors that are thought to affect the distribution and abundance of lithistids include availability of hard substrate (steep-sided seamounts, continental margins, carbonate rubble), ocean circulation, food, and silica availability (hydrothermally active sites high in silica vs. oceanic waters low in silica, etc.), but direct evidence of the particular role of those factors is not generally available. We do have direct evidence of the role of climate change; however, the distribution of New Zealand fossil and living lithistid faunas are remarkably disjunct; a rich fossil fauna existed off the South Island during the Late Eocene, but these species and genera only occur north of Chatham Rise today (Kelly 2007). Likewise, reproductive processes and how they might impact the formation of dense aggregations or diverse assemblages remain largely unknown. Nevertheless, a first molecular approach indicated that populations of several lithistids stay relatively well connected across distant deep seamounts off New Caledonia (Ekins et al. 2015), suggesting that at least some lithistids have unknown mechanisms for long-distance dispersal.

\section{Carnivorous Sponge Grounds}

Carnivorous sponges (Class Demospongiae, Family Cladorhizidae) are a group of typically deep-water sponges that feed on live macroscopic prey (Vacelet and BouryEsnault 1995) rather than filter feed; they lack the aquiferous system and special feeding cells (choanocytes) considered to be diagnostic for the Porifera. They are often shaped to increase surface area and consequently the chances of passively contacting prey; they are either asymmetrical, divaricating in a tree-like shape, or are symmetrical with profiles resembling those of feathers, palm trees, dandelions, or sunflowers. Most possess lateral filaments covered by "C"-shaped microsclere spicules that act as tiny hooks to capture small crustaceans by their bristles. Digestion is intracellular, accomplished by the migration of cells to the site of struggle, overgrowth phagocytosis, and encapsulation of the prey.

Carnivorous sponges are distributed globally but seem to be most common in deep-water environments such as hadal trenches, seamounts, mid-ocean ridges, volcanic arcs, methane seeps associated with accretionary prisms and hydrothermal vents. The deep southwest Pacific waters surrounding New Zealand present a highly diverse and frequently novel fauna, with over 30 species representing almost all known genera. Numerous sites on the Macquarie Ridge are dominated by cladorhizid sponges (Fig. 7a, b) unusually diverse in genera and species, and many other invertebrates live in close proximity. They contrast with monospecific 


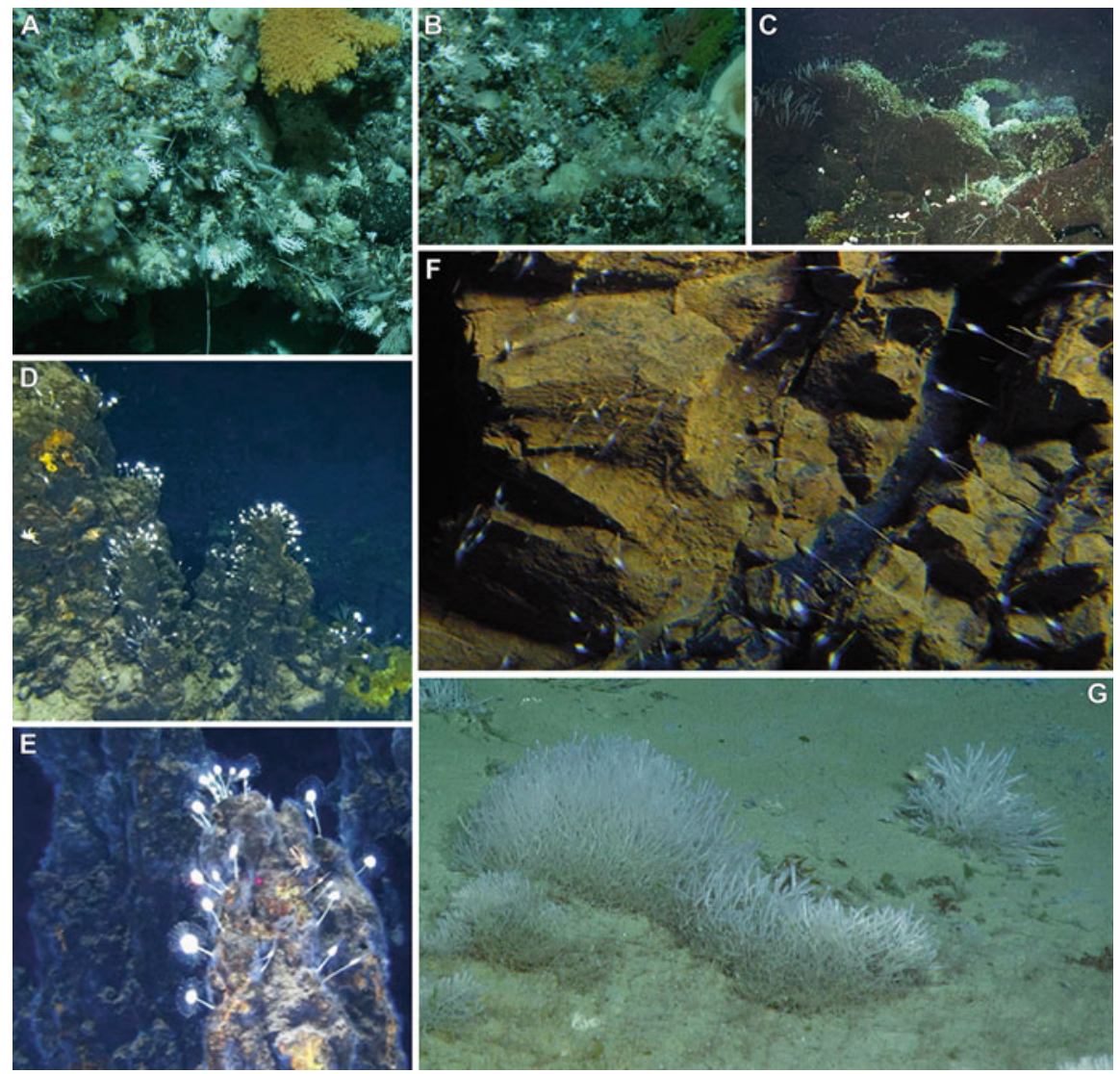

Fig. 7 Views of carnivorous sponge aggregations (A, B) Cladorhizidae garden on Seamount 7 at Macquarie Ridge (Australian Exclusive Economic Zone around Macquarie Island), 53.430 $\mathrm{S}$, $159.075^{\circ} \mathrm{E}, 845-900 \mathrm{~m}$. The sponges grow on a bottom substrate comprised of boulders, cobbles, gravel, sand, and shell fragments. (C) Field of Euchelipluma pristina on Candelabrum Meadow, a diffuse vent site at $1,500 \mathrm{~m}$ depth, on the Lilliput hydrothermal vent field on the southern mid-Atlantic Ridge (MAR) to the southeast of Ascension Island. Reproduced with permission from InterRidge News (2006) 15: 9-15 where it was first published. (D, E). Abyssocladia lakwollii in situ, images taken from remote-operated vehicle $(R O V)$, far eastern Solomon Islands: (D) sponges clustered on hydrothermal chimneys; (E) close-up image of sponges showing halo of lateral filaments. (F) Aggregation of Abyssocladia cf. bruuni attached to pillow lava in the southwest breach of Vailulu'u Seamount off American Samoa. (G) Dense gardens of methanotrophic sponges, Cladorhiza methanophila at a deep site of methane seepage $(5,000 \mathrm{~m}$, Atalante, Barbados accretionary prism)

aggregations described for Euchelipluma pristina (Fig. 7c) at the Lilliput hydrothermal vent field southeast of Ascension Island at a depth of 1,500 m (Koschinsky et al. 2006), Abyssocladia lakwollii (Fig. 7d, e) at hydrothermal vents around $1,000 \mathrm{~m}$ near the Solomon Islands (Vacelet and Kelly 2014), and Abyssocladia cf. bruuni (Fig. 7f) near vents off American Samoa (Staudigel et al. 2006). Densities 
of carnivorous sponges have seldom been estimated quantitatively. The abundance of Chondrocladia lampadiglobus on the east Pacific Rise between 2,586 and 2,684 m depth was estimated at 1-2.6 individuals $\mathrm{km}^{-1}$, whereas on a Pacific abyssal plain rich in polymetallic nodules, density has been estimated at 16, 4, and 5 individuals ha ${ }^{-1}$ for Chondrocladia, Cladorhiza, and Asbestopluma, respectively.

A remarkable example of much denser monospecific aggregations is provided by the stalked Abyssocladia cf. bruuni (Fig. 7f) at $600 \mathrm{~m}$ depth on the rim of Vailulu Seamount, an active underwater volcano east of Tau in American Samoa (Staudigel et al. 2006). Significant portions of the seamount's flank, rim, and caldera were explored, but cladorhizid sponges were found only in a single shallow breach (low area of the rim) on the southwest side. A current meter deployed for 2 months near the sponges revealed semidiurnal tidal cycles with long periods of inflowing current (15-30 $\mathrm{cm} \mathrm{s}^{-1}$ ) alternating with short periods of export at slower current speed $\left(10 \mathrm{~cm} \mathrm{~s}^{-1}\right)$. Sponges were oriented in such a way as to present the maximum exposure of their filaments to the prevailing currents, suggesting that sponges may rely on plankton transported into the volcano from the surrounding ocean.

The ecology of carnivorous sponges in mid-ocean habitats is poorly understood. Their populations are remote, isolated, and usually not the primary focus of the expeditions that lead to their discovery. However, an easily accessible Mediterranean cave population of Lycopodina hypogea (Vacelet and Boury-Esnault 1995) has afforded researchers a remarkable model for the study of feeding, digestion, longevity, and reproduction. The ability to culture these shallow cladorhizids will potentially help us understand the success of carnivorous sponges in the deep sea.

While most sponge aggregations increase habitat complexity and biodiversity, aggregations of carnivorous sponges may function in the opposite way. Although the observational evidence of carnivorous sponges capturing invertebrate larvae is very limited, it cannot be ruled out that fields of carnivorous sponges may reduce the likelihood that larvae of other invertebrates will reach the bottom. Preliminary feeding experiments of Lycopodina hypogea with larvae of the polychaete Malacoceros fuliginosa revealed that a few larvae were trapped and digested, but trapping success was low compared to that of copepods or mysids, probably because polychaete larvae have scarce and few setae. Whether carnivorous sponges can also be cannibalistic on conspecific larvae remains unknown. Genetic characterization of material ingested by L. hypogea showed that its prey belong to a large taxonomic range, including copepods, polychaetes, brittle stars, and nematodes (Rastorgueff et al. 2015). Some carnivorous sponges may complement their diet by symbiosis with methanotrophic bacteria (Vacelet et al. 1995), a feeding ability that probably allows them to aggregate around vent and seep habitats as well as other extreme environments that are uninhabitable to most other sponges. Methanotrophic sponges were discovered at 5,000 $\mathrm{m}$ depth on the edge of the Barbados accretionary prism, where extensive aggregations of Cladorhiza methanophila (Fig. 7e) were only found in areas of methane seepage, generally associated with sea anemones and the methanotrophic clam Abyssogena southwardae.

The reproduction of cladorhizids is poorly known, but it is suspected that some reproductive traits may facilitate the establishment of aggregations. Carnivorous 
sponges appear to be hermaphrodites that brood embryos and larvae. Unlike all other sponges, the sperm cannot be spawned in the water outflow because carnivorous sponges lack functional aquiferous canals. Rather the cysts in which the spermatozoids become mature develop a thick envelope that incorporates spicules sticking out of its surface. These spermatophore-like structures migrate through the mesohyl and leave the sponge body. The protruding spicules operate as buoyancy devices, but also allow spermatophores to be captured easily by conspecifics. Local hydrodynamics must therefore be important in establishing aggregations and determining population structure. It is suspected that oocytes may remain arrested in an early stage of oogenesis and that oocyte maturation is triggered by spermatophore capture (Lee et al. 2012). Although this mechanism, if confirmed, will increase the probability of fertilization, an even more interesting idea is that large mature zygotes may remain in developmental arrest awaiting some cue of a favorable environment (e.g., increased frequency of prey capture), so that juvenile sponges would be produced only during times of adequate food availability. Massive release of arrested zygotes could also favor the formation of aggregations. Most factors that help maintain aggregations including dispersal abilities of the larvae, longevity, predators, and other mortality sources remain unknown.

\section{$8 \quad$ Antarctic Aggregations}

After more than 100 years of research, over 400 species of sponges are known from the Southern Ocean. Most records come from the continental shelves and slopes (Janussen and Downey 2014), but abyssal plaines have also started being explored (Janussen and Tendal 2007; Göcke and Janussen 2013). The Antarctic sponge fauna shows some special traits and covers a broad diversity in many parameters. The endemism is pronounced (about $60 \%$ of the species) and the taxonomic homogeneity of the fauna along the almost $40,000 \mathrm{~km}$ long coastline is remarkable (Downey et al. 2012), favored by the circumpolar current and the eurybathy of many sponges species. These general patterns are suspected to be modified in the still poorly known deep-sea Antarctic environments (Brandt et al. 2007), because the barrier effect of the polar front $(\mathrm{PF})$ reduces with depth and allows some faunal exchange. As to diversity, some species are minute while others reach a height of up to $2 \mathrm{~m}$. While most species are white, yellow, beige, or grey, some are black, brown, carmine, or intensive green. A broad variety of substrates, among them sponge spicule mats that vary from $1 \mathrm{~cm}$ to $1 \mathrm{~m}$ in thickness, are often utilized, and a few species live buried in the sediment. Most are free living, others live as epibionts on other sponges, clams, and even on brittle stars, as is the case of Iophon radiatum growing on the ophiuroid Ophioplinthus spp. (Gutt and Schickan 1998). The great majority are filter feeders, but there are also some carnivorous species. Around the continent, sponge grounds occur both as almost monospecific and as quite diverse assemblages. The composition of the last mentioned is unique and heterogeneous, and their occurrence covers extreme ranges from absence in some Antarctic subregions to world records in 
biomass caused by ecological drivers of which some Antarctic specific are well known, while others still are to be deciphered.

It has been estimated that, on the relatively well-known Antarctic shelf, the sponge assemblages occupy about $10 \%$ of area and host an average biomass of about $12.7 \mathrm{~kg}$ of sponge wet weigh $\mathrm{m}^{-2}$ (Gutt et al. 2013). Some local studies also provide a more detailed description of the local patterns in sponge biomass distribution. A benthic biomass survey in the southeastern Weddell Sea shelf found three faunistic clusters of which two had only proportions between $0.5 \%$ and $4.2 \%$ of sponges. In the third, sponges were dominant with $43.3 \%$ of the total biomass (Gerdes et al. 1992). Values varied, especially in the sponge community with striking differences between stations. The sponge community had 3 out of 21 stations with no sponges at all, 8 stations had less than $10 \mathrm{~g} \mathrm{~m}^{-2}, 6 \mathrm{had} 10-100 \mathrm{~g} \mathrm{~m}^{-2}, 3 \mathrm{had}$ $100-1,000 \mathrm{~g} \mathrm{~m}^{-2}$, and the highest value was $1.4 \mathrm{~kg} \mathrm{~m}^{-2}$. Different studies on the composition of the sponge fauna in the same area showed that hexactinellids, Rossella and Anoxycalyx species (Fig. 8a-c), as well as demosponges, most dominant Cinachyra spp. (Fig. 8d), contribute to such biomass values with highly variable patchiness between both groups and within these taxa (Barthel and Gutt 1992). Independent of the abundance, the sea floor was almost totally covered by sponges where biomass was highest. Similarly, a study based on nine stations north and south of King George Island (South Shetland Islands) between 120 and 2,000 m depth found values of $>100$ and $10-100 \mathrm{~g}$ of sponge biomass $\mathrm{m}^{-2}$ at one station each, while four stations had no sponge at all (Piepenburg et al. 2002).

These Antarctic sponge populations also show surprising dynamics. At McMurdo Sound, a very dense recruitment of the demosponge Homaxinella balfourensis (Fig. 8e, f) covered up to $80 \%$ of the bottom surface over $1 \mathrm{~km}$. The population explosion occurred over a few years in the 1970 s when there was reduced anchor ice formation in the 15-30 m depth zone but, when the anchor ice returned, it carried the entire population away. In this case, no Homaxinella settled in the deeper habitats covered with a spicule matrix (Dayton 1989). In subsequent years, Homaxinella settled ubiquitously but only on artificial substrata (old cages, floating settlement surfaces, and even on pipes marking transects), rarely in the disturbed zone, and never on deeper natural surfaces. It would appear that the larvae are very motile and well dispersed but do not survive well when settling on natural surfaces because of postsettlement predation. In other areas and below $30 \mathrm{~m}$ depth, Homaxinella spp. recolonize areas disturbed by grounding glaciers or by scouring icebergs. They can dominate an initial low-diversity pioneer assemblage but are rare in more mature and diversified communities.

Another McMurdo Sound species, the less opportunistic, very large hexactinellid Anoxycalyx joubini showed no detectable recruitment from the 1960s through 1989, but then it had a population explosion in which it settled only on artificial substrata, sometimes in such large numbers that their growth pushed them off the structure onto the bottom where they almost always die as a consequence of predation (Dayton et al. 2013). Here, the lack of settlement on natural substrata suggests very effective predators (potentially all the predators from foraminifera, polychaetes, crustaceans, to echinoderms) on the small larvae and recruits. There are other almost 

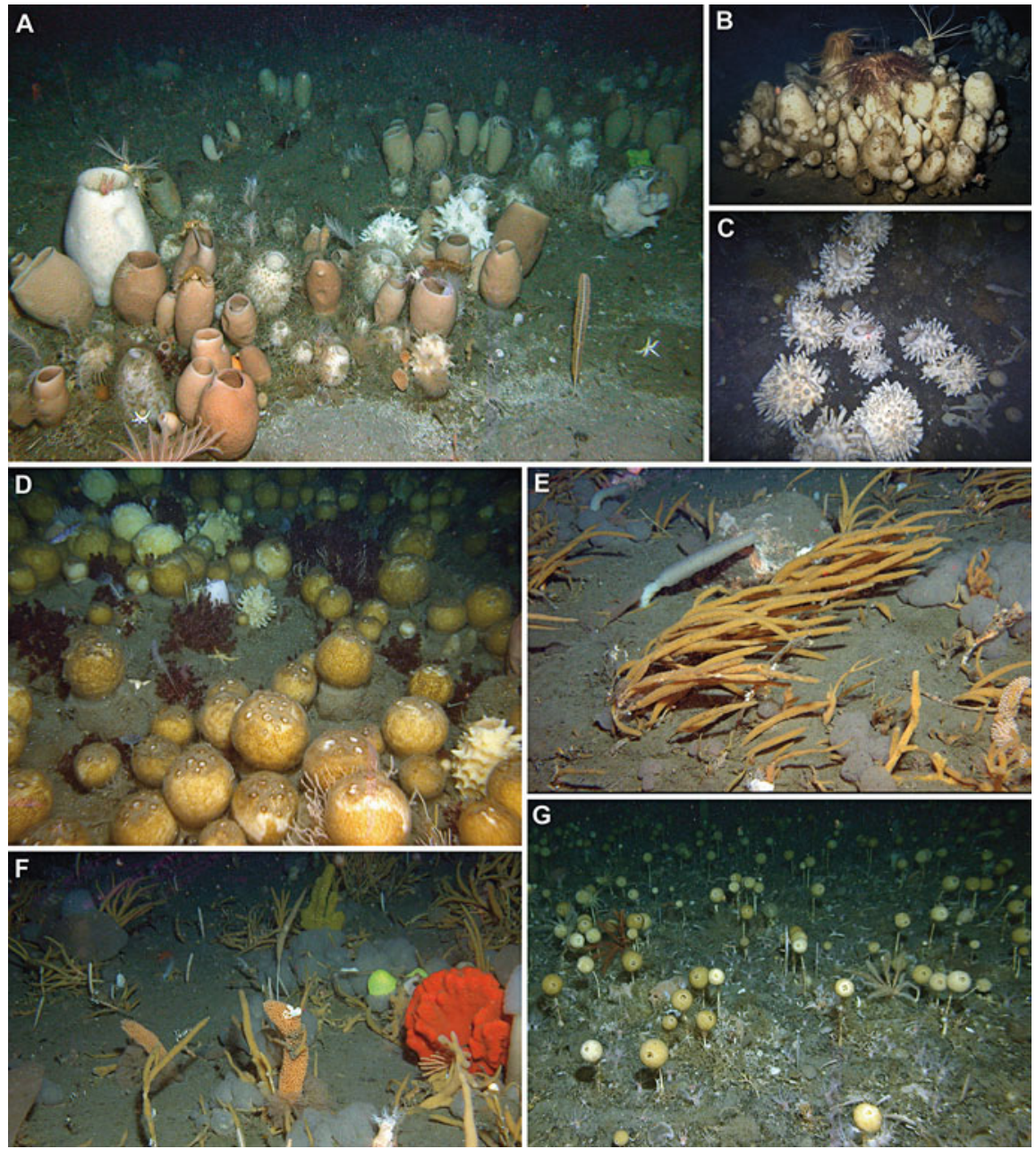

Fig. 8 Views of Antarctic aggregations. (A) A benthic assemblage in the Southeastern Weddell Sea (Antarctica) at approximately $233 \mathrm{~m}$ water depth. It is dominated by glass sponges, Anoxycalyx joubini and Rossella spp, with a rich associated fauna of echinoderms and cnidarians, indicating that this habitat has not been disturbed by ice scouring for a relatively long period. (B) Detail of a large clump of Rossella podagrossa formed by budding and photographed at $50 \mathrm{~m}$ in 1974 in the Ross Sea. Reproduced with permission of Magnolia Press from Zootaxa (2015) 1: 169-177, where it was first published. (C) Detail of a small aggregation of the spiky hexactinellid Rosella racovitzae or R. nuda photographed using a small ROV designed to go down through $12 \mathrm{~cm}$ holes drilled in the ice. (D) A nearly monospecific aggregation of the demosponge Cinachyra barbata s.l., in the Southeastern Weddell Sea at $250 \mathrm{~m}$ depth. (E, F). Benthic assemblage east of the Antarctic Peninsula at $210 \mathrm{~m}$. They are dominated by Homaxinella balfouriensis, with abundance of other erect demosponges, including the reddish Kirkpatrickia variolosa, and a rich associated fauna of compound sea-squirts (translucid white) and sea-fans. (G) Aggregation of "lollipop" sponges (herein Stylocordyla chupachups) with associated bryozoans, ascidians, and cnidarians. These assemblages are common at an intermediate stage of bottom recolonization after iceberg scouring 
monospecific aggregations in deeper water of large Rossella spp. that appear to result from asexual reproduction of recruits that escape predation (Fig. 8b). On the southeastern Weddell Sea shelf, sea-bed images showed a size-depending proportion of budding specimens of the species complex Rossella nuda or A. joubini ranging from approximately 3-76\% and small-scale patches of budding $R$. racovitzae specimens (Barthel and Gutt 1992).

Also in McMurdo Sound, Rossella podagrosa has been observed to disperse by small buds that break off and float away in the currents. In areas with reduced currents, this asexual reproduction results in patterns of clumped specimens that tend to characterize the distribution of the species (Fig. 8b). This mode of reproduction might also have been evolutionary advantageous for other rossellids during ice ages, when most of the Antarctic shelf was covered by grounded inland ice. Budding, although reducing genetic diversity and favoring endogamy in the long term, would enable the successive generations of the shelf species to establish in small refuge areas and not being drifted away as larvae to hostile deep-sea environments. Indeed, as larvae of most hexactinellids, rossellids included, remain "unseen", molecular studies should confirm that those so-called "asexual buds" are not juveniles derived from a process of sexual reproduction by direct development (i.e., lacking a larval stage), as is known for spirophorid demosponges. Sphirophorids, of which the genera Cinachyra and Tetilla form extensive sponge grounds in some Antarctic shelves, lack the larval stage, and rely for propagation on nonswimming "bud-like" propagules (Fig. 1b, c), which, indeed, are juvenile sponges grown within the maternal body through a process of sexual reproduction with internal fertilization, brooding, and direct development. As these unciliated propagules, charged with a heavy spicule skeleton at the time of crawling out of the maternal body, often fall right by the side of the mother sponge, they favor the formation of dense aggregations.

Iceberg scouring shapes sponge grounds significantly, a phenomenon well studied in the Weddell Sea. Above all, it causes high mortality and formation of sponge spicule mats that serve as a substratum for other organisms. Scouring also buries biogenic silicon in the sediment. It is an open question whether the lower limit of high-diversity sponge grounds coincides by chance with the lower limit of abundant scouring by icebergs or whether iceberg-scouring stimulates the development of sponge grounds. It has been shown that iceberg scouring shapes the diversity of coexisting stages of recolonization by sponges (Fig. 8g), characterized by demosponges, sometimes by hexactinellids, and in some areas by fast growing species or, in other areas, by long-lived species. Benthic communities beneath ice shelves were often assumed to be poor in diversity and biomass, as inputs into the local trophic chain were restricted to limited external food arriving by advection. Interestingly, carnivorous species are found in these areas. Ocean and atmospheric warming is also favoring that $23,000 \mathrm{~km}^{2}$ of such continental shelf areas start developing high levels of primary production upon ice shelf disintegration. Such a food inflow caused in the Larsen A area after 12 years, but not yet in the Larsen B embayment after 5 years, a sudden recruitment of hexactinellid sponges (Gutt et al. 2011). After a further 4 years, a twofold to threefold increase in number of 
individuals and a dry biomass increase of hexactinellids and demosponges from 17.5 to $32.5 \mathrm{~g} \mathrm{~m}^{-2}$ was described (Fillinger et al. 2013). These new findings suggest that hexactinellids can be ecological pioneers. These species also appear to be able to arrest their growth and reproductive activity for decades until favorable conditions return and trigger explosive body growth and reproductive activity. The regression of the ice cover is making evident that Antarctic sponge aggregations may be substantially shaped by not only ice scouring and predator abundances but also by food delivery patterns. Reciprocally, the explosive growth and decline of the sponge populations is thought to have a nonnegligible impact on the benthic-pelagic coupling of major flows of particulate food and silica at the habitat level (Maldonado et al. 2012; Gutt et al. 2013; Sañé et al. 2013).

From the rare occurrence of adult glass sponges in still or formerly ice-shelf covered areas, we learn that they do not necessarily need much food. When ice shelves disintegrate, some species recruit very successfully, indicating that higher food supply supports their success. A general conclusion from these observations is that such specimens reach such remote areas as larvae that are brought in by currents and experience high mortality, because juveniles are especially sensitive to food limitation. Such complexity in ecological demands and life performance could also explain their highly unpredictable occurrence in non-ice-covered habitats.

The role of sponges and other macroinvertebrates in adding three-dimensional structure to Antarctic benthic habitats and increasing the biodiversity of their associated fauna is described in detail in the chapter " $>$ Antarctic Marine Animal Forests" by Gutt et al.

\section{Conservation Concerns for Sponge Aggregations}

The main threats to the structure and ecological functioning of virtually all types of sponge aggregations are mechanical damage and general habitat destruction derived from either physical damage or pollution. In many aggregations, the risk of mechanical damage is primarily from bottom-fishing activities (e.g., longlining, benthic gillnets, benthic traps, trawling, etc.). For some aggregations, particularly glass sponge reefs, longlining may be just as problematic as trawling, because very long fishing lines easily slice through sponges. In areas where trap or pot fishing is used, they may damage sponge aggregations during recovery. In addition to these direct impacts caused by physical contact, sponges may suffer indirect impacts of chronic trawling through increased sediment loads causing smothering.

Until recently, physical damage of benthic habitats and organisms mostly occurred as a result of fishing activities. However, more recently the causes have expanded to include other industrial activities, such as dredging, oil and gas prospecting and exploitation, and deep-sea mining. The latter activity in particular is threatening a number of pristine sponge aggregation types found on shelf breaks, slopes, seamounts, and hydrothermal vents. A striking example is the lithistid reeflike formation recently discovered on a Mediterranean seamount that is the target of imminent plans for prospecting and exploitation of oil and gas (Fig. 9). Preservation 


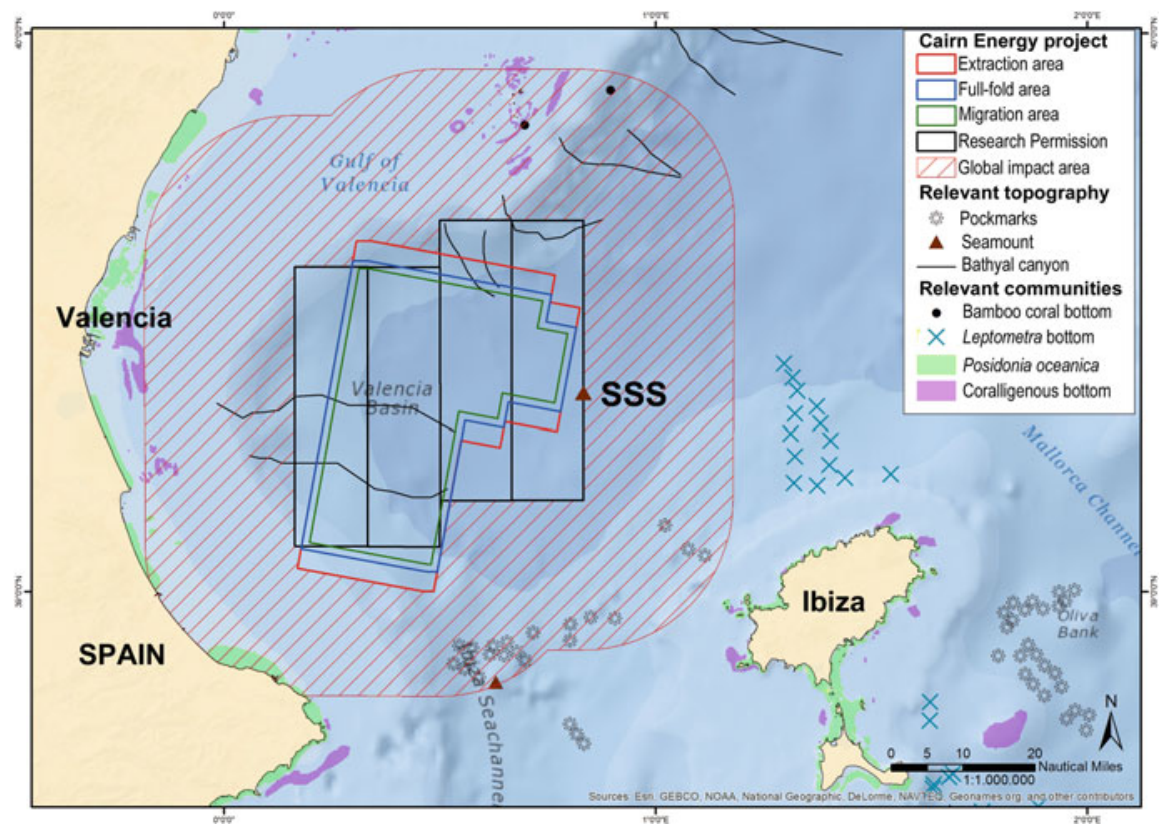

Fig. 9 Example of interaction between commercial exploitation of seamounts and vulnerable sponge aggregation in the Western Mediterranean. The map has been elaborated using public information available from the Spanish Ministry of Industry, Energy and Tourism, published in the Spanish Boletín Oficial del Estado $(B O E)$ and at the Ministry webpage:http://www6.mityc.es/ aplicaciones/energia/hidrocarburos/petroleo/exploracion2014/mapas/inicio.html. The company Cairn Energy has requested permission (i.e., Cairn project) to seismic prospecting, to research, and to extract hydrocarbons from a large bathyal area between the Spanish Coast and the Balearic Island of Ibiza (Mediterranean Sea). The area of interest includes the SSS seamount, that is, the site where the unique lithistid reef-like aggregation, reminiscent of analogous Jurassic formations, occurs. The global impact area is estimated as an outer, $30 \mathrm{~km}$-wide belt around the zone of activity

of seamount habitats is also important for carnivorous sponges, a small but fascinating group of sponges that are critically important for seamount ecology. Direct habitat destruction is also a major concern for mangroves worldwide and, consequently, to their distinct associated underwater sponge communities.

While physical damage to sponge aggregations and their habitats is relatively easy to identify at shallow depths through direct observation, the conservation status of deep-water sponge aggregations is often hard to evaluate due to their remoteness. In the northwest Atlantic, important Geodia-dominated sponge grounds have been protected by the Northwest Atlantic Fisheries Organization from bottom fishing in the international waters east of Newfoundland, Canada. That protection was stimulated through the United Nations General Assembly resolution 61/105 which calls for the protection of vulnerable marine ecosystems (FAO 2009), including sponge grounds. The closure of these areas may be the first created specifically to protect sponges. However, in general, suitable long-term management strategies are difficult 
to put in place due to knowledge gaps related to longevity, reproduction, and connectivity. In these areas, restoration plans are even more problematic due to this same knowledge deficiency. Modern technology is helping in some cases, where damaged grounds or dead reef mounds can be detected by examining sonograms that show obvious trawl marks on the seabed or through use of underwater cameras, ROVs, and manned submersibles.

With the advent of industrial underwater and coastal technologies, the ways habitats are affected by physical and chemical damage continue to increase and diversify, including increased exposure to sedimentation, suspended sediment plumes, and waste chemical discharges (including undesirably frequent shallowwater and deep-sea oil spills). In addition, there is also increasing exposure of sponges to episodic environmental and biological stressors. These include sudden temperature stress events, increased influx of organic carbon (e.g., as a function of sea ice retreating in high latitudes or man-driven nutrient discharges in coastal areas), and frequent incidences of disease outbreaks as a function of climate change and ocean acidification. Irrespective of their exact causes, diseases are becoming a serious threat to many shallow-water temperate and tropical sponge communities.

\section{Conclusions and Future Directions}

Although the role of sponge aggregations as builders of complex three-dimensional habitats has often been discussed, sponge biomass has seldom been measured accurately and, fluxes of matter and energy through sponges have been quantified even less often. Functional information is fundamental if benthic ecologists are to fully acknowledge the importance of sponge aggregations in marine ecosystems and communities. It has been recently demonstrated that sponges fuel the food chains of oligotrophic reef systems. They feed on bacteria as a main $\mathrm{C}$ source, but they also incorporate the DOM available in the water column of oligotrophic reefs, a resource that is not assimilated by most other invertebrates. In turn, energy from DOM is converted to POM resulting from cell renewal, but also abundant metabolic wastes, that escapes from the sponges, providing assimilable $\mathrm{C}$ and $\mathrm{N}$ to fuel the food chains of oligotrophic reefs. Whether this mechanism also operates in oligotrophic food chains of deep-sea systems remain to be addressed.

It has often been assumed that sponge aggregations are not food limited, but some of the information reviewed herein suggests otherwise. Studies of several bathyal aggregations indicate that periodic inputs of food from the upper ocean trigger peaks of growth and reproductive activity, hinting that the aggregations may be food limited during most of the year or even across multiple years. Compelling evidence also comes from the melting of Antarctic ice that promotes primary production on the ice-free continental-shelf while triggering major reorganizations in the sponge communities, including astonishing peaks of growth and/or recruitment. The hypothesis of food limitation in dense, multispecific sponge communities on coral reefs was proposed in the 1970s, but never proven, and has therefore been disregarded by most scientists. Observations that carnivorous sponges typical of 
oligotrophic bathyal environments are able to arrest many of their physiological functions during long periods also support the idea that these sponges experience food limitation over long periods of the year. Therefore, the impact of sponge aggregations on local food chains, the possibility of food limitation, and the ecological consequences of both processes emerge as major topics for future investigation. The ecological impact of the fluxes of inorganic nutrients ( $\mathrm{Si}$ and $\mathrm{N}$ compounds) derived from either the biological activity of the sponges themselves or their associated microbiomes also remain to be evaluated for most sponge communities. This topic may be particularly important in deep-water aggregations.

Very little is known about reproductive biology and its impact on population structure for most of the sponge aggregations dealt with in this chapter. This major gap in knowledge is particularly important for the conservation of these unique and vulnerable communities. Sexual reproduction by direct development (i.e., in absence of a larval stage) produces dispersing juveniles (Fig. 1b, c) that land near the parent, and it has been suggested that this limited dispersal favors aggregations of spirophorids in the Antarctic (Fig. 8d), Boreal North Atlantic, and elsewhere (Fig. 1a). Likewise, asexual reproduction by budding of nonmotile propagules may favor the aggregation of at least some hexactinellids in the Antarctic sponge communities. However, this pattern may not be the rule for other hexactinellid aggregations, as molecular genetic data on the population structure of glass sponge reefs indicate no cloning, even within clumps of individuals. Recent molecular data also show significant genetic exchange over large distances for deep-sea lithistid communities, coral reef sponges, and several other sponge aggregations. It is evident that unraveling the development and larval ecology of dominant species is crucial if we are to ever understand how those aggregations are formed and maintained. Evidence from Antarctic and coral reef aggregations indicates that predation is another important factor controlling the formation and persistence of the aggregations, but it remains unknown how this factor affects most of the other aggregation types reviewed herein.

In summary, the few functional studies available suggest that sponge aggregations in both shallow and deep waters are singular, vulnerable systems. Available evidence suggests that these aggregations influence the functioning of surrounding at the local and regional scales by participating in the benthic-pelagic coupling of pivotal inorganic nutrients and organic matter. Yet, despite their anticipated ecological and functional relevance, these sponge-dominated systems remain largely understudied and rarely fall under the protection of environmental legislation.

Acknowledgments The authors thank colleagues and institutions for kind picture contributions: Kevin Coate (Fig. 1a), Tracey Bates (Fig. 3c-e), Chip Clark (Fig. 3a, b), and Carla Piantoni (Fig. 3c), Institute of Marine Research (Figs. 1b, c and 4b), Department of Fisheries and Oceans Canada (Fig. 6c, d), National Institute of Water and Atmospheric Research (NIWA) of New Zealand (Figs. 6d and 7a, b), and Neptune Minerals Inc. (Fig. 7d, e), and Alfred Wegener Institute/Marum, University of Bremen, Germany (Fig. 8a, 8d-g). This study has benefitted from funding by the Spanish Ministry of Economy and Competitiveness (CTM2012-37787) to MM; from the Caribbean Coral Reef Ecosystems Program and the National Museum of Natural History, Washington to KR, $\mathrm{CD}$, and MM (Contribution Number 986); from Stiftung Drittes Millennium, Fundación Biodiversidad, and the Ministerio de Agricultura, Alimentación y Medio Ambiente to Oceana 
and RA; from NIWA, New Zealand Foundation for Research, Science and Technology, and CSIRO's Division of Marine and Atmospheric Research to MK; the Natural Sciences and Engineering Council of Canada for Discovery and Ship Time grants to SPL; from the Norwegian Research Council to RJB and HTR; from The Norwegian Oil and Gas and the Norwegian Biodiversity Information Centre to HTR; and from the Natural Sciences and Engineering Council of Canada for Discovery and Ship Time grants to SPL.

\section{Cross-References}

Antarctic Marine Animal Forests - Three-Dimensional Communities in Southern Ocean Ecosystems

- Benthic-Pelagic Coupling: New Perspectives in the Animal Forests

- Conservation and Management of Vulnerable Marine Benthic Ecosystems

- Ecosystem Functions and Services of the Marine Animal Forests

- Energetics, Particle Capture, and Trophic Ecology of Suspension Feeders

- Filter-Feeding Zoobenthos and Hydrodynamics

- The Connection of the Animal Forest with Land Ecosystems: The Example of Mangroves

\section{References}

Arellano S, Lee O, Lafi F, Yang J, Wang Y, Young C, et al. Deep sequencing of Myxilla (Ectyomyxilla) methanophila, an epibiotic sponge on cold-seep tubeworms, reveals methylotrophic, thiotrophic, and putative hydrocarbon-degrading microbial associations. Microb Ecol. 2013;65(2):450-61. doi:10.1007/s00248-012-0130-y.

Barthel D, Gutt J. Sponge associations in the eastern Weddell Sea. Antarct Sci. 1992;4(2):137-50.

Beazley L, Kenchington E, Yashayaev I, Murillo FJ. Drivers of epibenthic megafaunal composition in the sponge grounds of the Sackville Spur, northwest Atlantic. Deep-Sea Res I. 2015;98:102-14.

Beazley LI, Kenchington EL, Murillo FJ, Sacau MDM. Deep-sea sponge grounds enhance diversity and abundance of epibenthic megafauna in the Northwest Atlantic. ICES J Mar Sci. 2013;70 (7):1471-90. doi:10.1093/icesjms/fst124.

Becking LE, Cleary DFR, de Voogd NJ. Sponge species composition, abundance, and cover in marine lakes and coastal mangroves in Berau. Indonesia Mar Ecol Prog Ser. 2013;481:105-20. doi:10.3354/meps10155.

Bell JJ, Davy SK, Jones T, Taylor MW, Webster NS. Could some coral reefs become sponge reefs as our climate changes? Glob Chang Biol. 2013;19:2613. doi:10.1111/gcb.12212.

Brandt A, Gooday AJ, Brandao SN, Brix S, Brokeland W, Cedhagen T, et al. First insights into the biodiversity and biogeography of the Southern Ocean deep sea. Nature. 2007;447 (7142):307-11.

Brown R. 2015. Reproduction and genetic structure in a reef-forming glass sponge, Aphrocallistes vastus. MSc Thesis, University of Alberta. https://era.library.ualberta.ca/files/n870zt81x\#. VtaVnK2DNTo.

Conway KW, Barrie JV, Austin WC, Luternauer JL. Holocene sponge bioherms on the western Canadian continental shelf. Cont Shelf Res. 1991;11(8-10):771-90.

Conway KW, Krautter M, Barrie JV, Whitney F, Thomson RE, Reiswig H, et al. Sponge reefs in the Queen Charlotte Basin, Canada: controls on distribution, growth and development. In: Freiwald A, Roberts JM, editors. Cold-water corals and ecosystems. Berlin: Springer; 2005. p. 605-21. 
Chu JWF, Maldonado M, Yahel G, Leys SP. Glass sponge reefs as a silicon sink. Mar Ecol Prog Ser. 2011;441:1-14.

Dayton PK. Interdecadal variation in an Antarctic sponge and its predator from oceanographic climate shifts. Science. 1989;245:1484-6.

Dayton PK, Kim S, Jarrell SC, Oliver JS, Hammerstrom K, Fisher JL, et al. Recruitment, growth and mortality of an Antarctic hexactinellid sponge, Anoxycalyx joubini. PLoS One. 2013;8(2):e56939.

de Goeij JM, van Oevelen D, Vermeij MJA, Osinga R, Middelburg JJ, de Goeij AFPM, et al. Surviving in a marine desert: the sponge loop retains resources within coral reefs. Science. 2013;342:108-10.

Diaz MC, Rützler K. Biodiversity and abundance of sponges in Caribbean mangrove: indicators of environmental quality. Smithson Contrib Mar Sci. 2009;38:151-72.

Diaz MC. Mangrove and coral reef sponge faunas: untold stories about shallow water Porifera in the Caribbean. Hydrobiologia. 2012;687(1):179-90. doi:10.1007/s10750-011-0952-5.

Dohrmann M, Göcke C, Reed J, Janussen D. Integrative taxonomy justifies a new genus, Nodastrella gen. nov., for North Atlantic "Rossella" species (Porifera: Hexactinellida: Rossellidae). Zootaxa. 2012;3383:1-13.

Downey RV, Griffiths HJ, Linse K, Janussen D. Diversity and distribution patterns in high southern latitude sponges. PLoS One. 2012;7(7):e41672.

Ekins M, Erpenbeck D, Hall K, Wörheide G, Hooper JNA. Staying well connected: lithistid sponges on seamounts. J Mar Biol Assoc UK. 2016;96(2):437-451. doi:10.1017/ S0025315415000831.

Ellison AM, Farnsworth EJ, Twilley RR. Facultative mutualism between red mangroves and rootfouling sponges in Belizean mangal. Ecology. 1996;77(8):2431-44.

Fallon SJ, James K, Norman R, Kelly M, Ellwood MJ. A simple radiocarbon dating method for determining the age and growth rate of deep-sea sponges. Nucl Inst Methods Phys Res B. $2010 ; 268(7-8): 1241-3$.

FAO. Report of the technical consultation on international guidelines for the management of deepsea fisheries in the high seas Rome: Food and Agriculture Organization of the United Nations. 2009. Report no. 881.

Fillinger L, Janussen D, Lundälv T, Richter C. Rapid glass sponge expansion after climate-induced Antarctic ice shelf collapse. Curr Biol. 2013;23(14):1330-4. doi:10.1016/j.cub.2013.05.051.

Gerdes D, Klages M, Arntz WE, Herman RL, Galéron J, Hain S. Quantitative investigations on macrobenthos communities of the southeastern Weddell Sea shelf based on multibox corer samples. Polar Biol. 1992;12(2):291-301. doi:10.1007/bf00238272.

Ghiold J. The sponges that spanned Europe. New Sci. 1991;129(1754):58-62.

Göcke C, Janussen D. Sponge assemblages of the deep Weddell Sea: ecological and zoogeographic results of ANDEEP I-III and SYSTCO I expeditions. Polar Biol. 2013;36(7-2):1059-68.

Guerra-Castro EJ, Cruz-Motta JJ. Ecology of fouling assemblages associated with mangrove's roots: an artificial substrate for manipulative experiments. J Exp Mar Biol Ecol. 2014;457:31-40. doi:10.1016/j.jembe.2014.03.017.

Gutt J, Schickan T. Epibiontic relationships in the Antarctic benthos. Antarct Sci. 1998;10:398-405.

Gutt J, Barratt I, Domack E, d'Udekem d'Acoz C, Dimmler W, Grémare A, et al. Biodiversity change after climate-induced ice-shelf collapse in the Antarctic. Deep-Sea Res II Top Stud Oceanogr. 2011;58(1-2):74-83. doi:10.1016/j.dsr2.2010.05.024.

Gutt J, Böhmer A, Dimmler W. Antarctic sponge spicule mats shape macrobenthic diversity and act as a silicon trap. Mar Ecol Prog Ser. 2013;480:57-71. doi:10.3354/meps10226.

Janussen D, Tendal OS. Diversity and distribution of Porifera in the bathyal and abyssal Weddell Sea and adjacent areas. Deep-Sea Res II. 2016;96(2):429-436. doi:10.1017/S0025315415000466.

Janussen D, Downey RV. Porifera. In: De Broyer C, Koubbi P, Griffiths H, Raymond B, d'Udekem d'Acoz C, Van de Putte A, editors. Biogeographic atlas of the Southern Ocean. Cambridge: Scientific Committee on Antarctic Research; 2014. p. 94-102.

Kahn A, Vehring L, Brown R, Leys S. Dynamic change, recruitment, and resilience in reef-forming glass sponges. J Mar Biol Assoc UK. 2016;96(2):429-436. doi:10.1017/S0025315415000466. 
Kahn AS, Yahel G, Chu JWF, Tunnicliffe V, Leys SP. Benthic grazing and carbon sequestration by deep-water glass sponge reefs. Limnol Oceanogr. 2015;60(1):78-88. doi:10.1002/lno.10002.

Kelly M. The marine Fauna of New Zealand. Porifera: lithistid Demospongiae (Rock Sponges), The marine fauna of New Zealand. Wellington: National Institute of Water and Atmospheric Research (NIWA); 2007.

Kelly M, Ellwood M, Tubbs L, Buckeridge J. The lithistid Demospongiae in New Zealand waters: species composition and distribution. In: Custódio MR, Lôbo-Hajdu G, Hajdu E, Muricy G, editors. Porifera research: biodiversity, innovation and sustainability, vol série livros. Rio de Janeiro: Museu Nacional du Rio de Janeiro; 2007. p. 393-404.

Klitgaard AB, Tendal OS. Distribution and species composition of mass occurrences of large-sized sponges in the northeast Atlantic. Prog Oceanogr. 2004;61(1):57-98. doi:10.1016/j. pocean.2004.06.002.

Knudby A, Kenchington E, Murillo FJ. Modeling the distribution of Geodia sponges and sponge grounds in the Northwest Atlantic. PLoS One. 2013;8(12):e82306.

Koschinsky A, Billings A, Devey C, Dubilier N, Duester A, Edge D, et al. Discovery of new hydrothermal vents on the southern Mid-Atlantic Ridge ( $\left.4^{\circ} \mathrm{S}-10^{\circ} \mathrm{S}\right)$ during Cruise M68/1. InterRidge News. 2006;15:9-15.

Krautter M, Conway KW, Barrie JV, Neuweiler M. Discovery of a "living dinosaur": globally unique modern hexactinellid sponge reefs off British Columbia, Canada. Facies. 2001;44:265-82.

Kuhnz LA, Ruhl HA, Huffard CL, Smith Jr KL. Rapid changes and long-term cycles in the benthic megafaunal community observed over 2 years in the abyssal northeast Pacific. Prog Oceanogr. 2014;124:1-11. doi:10.1016/j.pocean.2014.04.007.

Kutti T, Bannister RJ, Fosså JH. Community structure and ecological function of deep-water sponge grounds in the Traenadypet MPA - northern Norwegian continental shelf. Cont Shelf Res. 2013;69:21-30. doi:10.1016/j.csr.2013.09.011.

Lee WL, Reiswig HM, Austin WC, Lundsten L. An extraordinary new carnivorous sponge, Chondrocladia lyra, in the new subgenus Symmetrocladia (Demospongiae, Cladorhizidae), from off of northern California, USA. Invertebr Biol. 2012;131(4):259-84. doi:10.1111/ ivb. 12001.

Lévi C. Lithistid sponges from the Norfolk rise. Recent and Mesozoic genera. In: Reitner J, Keupp H, editors. Fossil and recent sponges. Berlin/Heidelberg/New York: Springer; 1991. p. $72-82$.

Leys SP, Lauzon RJ. Hexactinellid sponge ecology: growth rates and seasonality in deep water sponges. J Exp Mar Biol Ecol. 1998;230:111-29.

Maldonado M, Carmona MC, Velásquez Z, Puig A, Cruzado A, López A, et al. Siliceous sponges as a silicon sink: an overlooked aspect of the benthopelagic coupling in the marine silicon cycle. Limnol Oceanogr. 2005;50(3):799-809. doi:10.4319/lo.2005.50.3.0799.

Maldonado M, Riesgo A, Bucci A, Rützler K. Revisiting silicon budgets at a tropical continental shelf: silica standing stocks in sponges surpass those in diatoms. Limnol Oceanogr. 2010;55 (5):2001-10. doi:10.4319/1o.2010.55.5.2001.

Maldonado M, Ribes M, Van Duyl FC. Nutrient fluxes through sponges: biology, budgets, and ecological implications. Adv Mar Biol. 2012;62:114-82. doi:10.1016/B978-0-12-3942838.00003-5.

Maldonado M. Sponge waste that fuels marine oligotrophic food webs: a re-assessment of its origin and nature. Mar Ecol. 2015;1-15. doi:10.1111/maec.12256.

Maldonado M, Aguilar R, Blanco J, García S, Serrano A, Punzón A. Aggregated clumps of Lithistid sponges: a singular, reef-like bathyal habitat with relevant paleontological connections. PLoS One. 2015;10(5):e0125378.

Murillo FJ, Muñoz PD, Cristobo J, Ríos P, González C, Kenchington E, et al. Deep-sea sponge grounds of the Flemish Cap, Flemish Pass and the Grand Banks of Newfoundland (Northwest Atlantic Ocean): distribution and species composition. Mar Biol Res. 2012;8(9):842-54. doi:10.1080/17451000.2012.682583. 
Piepenburg D, Schmid M, Gerdes D. The benthos off King George Island (South Shetland Islands, Antarctica): further evidence for a lack of a latitudinal biomass cline in the Southern Ocean. Polar Biol. 2002;25(2):146-58. doi:10.1007/s003000100322.

Pile AJ, Young CM. The natural diet of a hexactinellid sponge: Benthic-pelagic coupling in a deepsea microbial food web. Deep-Sea Res I Oceanogr Res Pap. 2006;53(7):1148-56.

Pomponi SA, Kelly M, Reed J, Wright AD. Diversity and bathymetric distribution of lithistid sponges in the tropical western Atlantic region. Bull Biol Soc Wash. 2001;10:344-53.

Rastorgueff PA, Rocher C, Selva M, Chevaldonné P. Preliminary DNA-based diet assessment of a gutless carnivore, the sponge Asbestopluma hypogea. J Exp Mar Biol Ecol. 2015;467:108-14.

Reiswig HM. Population dynamics of three Jamaican Demospongiae. Bull Mar Sci. 1973;23:191-226.

Reiswig HM. Water transport, respiration and energetics of three tropical marine sponges. J Exp Mar Biol Ecol. 1974;14:231-49.

Rice AL, Thurston MH, New AL. Dense aggregations of a hexactinellid sponge, Pheronema carpenteri, in the Porcupine Seabight (northeast Atlantic Ocean), and possible causes. Prog Oceanogr. 1990;24:179-96.

Rützler K. Low-tide exposure of sponges in a Caribbean mangrove community. Mar Ecol. 1995;16 (2):165-79. doi:10.1111/j.1439-0485.1995.tb00402.x.

Rützler K, Díaz MC, van Soest RWM, Zea S, Smith K, Alvarez B, et al. Diversity of sponge fauna in mangrove ponds, Pelican Cays, Belize. Atoll Res Bull. 2000;477:231-50.

Rützler K. The role of sponges in the Mesoamerican barrier-Reef ecosystem, Belize. In: Becerro MA, Uriz MJ, Maldonado M, Turon X, editors. Adv Mar Biol. 2012;61(61):211-271. doi:10.1016/B978-0-12-387787-1.00002-7.

Sañé E, Isla E, Bárcena MÁ, DeMaster DJ. A shift in the biogenic silica of sediment in the Larsen B continental shelf, off the eastern Antarctic Peninsula, resulting from climate change. PLoS One. 2013;8(1):e52632.

Schönberg C, Fromont J. Sponge gardens of Ningaloo Reef (Carnarvon Shelf, Western Australia) are biodiversity hotspots. Hydrobiologia. 2012;687(1):143-61. doi:10.1007/s10750-011-0863-5.

Staudigel H, Hart SR, Pile A, Bailey BE, Baker ET, Brooke S, et al. Vailulu'u Seamount, Samoa: life and death on an active submarine volcano. Proc Natl Acad Sci. 2006;103(17):6448-53. doi:10.1073/pnas.0600830103.

Tompkins-MacDonald G, Leys S. Glass sponges arrest pumping in response to sediment: implications for the physiology of the hexactinellid conduction system. Mar Biol. 2008;154(6):973-84. doi:10.1007/s00227-008-0987-y.

Vacelet J, Boury-Esnault N. Carnivorous sponges. Nature. 1995;373(6512):333-5. doi:10.1038/ $373333 \mathrm{a} 0$.

Vacelet J, Boury-Esnault N, Fiala-Medioni A, Fisher CR. A methanotrophic carnivorous sponge. Nature. 1995;377:296.

Vacelet J, Kelly MA. New species of Abyssocladia (Porifera, Demospongiae, Poecilosclerida, Cladorhizidae) and other carnivorous sponges from the far eastern Solomon Islands. Zootaxa. 2014;3815(3):11. doi:10.11646/zootaxa.3815.3.4.

Wiedenmayer F. Contributions to the knowledge of post-Paleozoic neritic and archibental sponges (Porifera). Schweiz Paläontol Abhand. 1994;116:1-147.

Wilkinson CR, Cheshire AC. Comparison of Sponge populations across the Barrier Reefs of Australia and Belize: evidence for higher productivity in the Caribbean. Mar Ecol Prog Ser. 1990;67:285-94.

Witte U. Seasonal reproduction in deep-sea sponges triggered by vertical particle flux? Mar Biol. 1996;124:571-81.

Witte U, Graf G. Metabolism of deep-sea sponges in the Greenland-Norwegian Sea. J Exp Mar Biol Ecol. 1996;198:223-35.

Wulff JL. Rapid diversity and abundance decline in a Caribbean coral reef sponge community. Biol Conserv. 2006;127:167-76. 